\title{
Synthesis, Antimuscarinic Activity and Quantitative Structure-Activity Relationship (QSAR) of Tropinyl and Piperidinyl Esters
}

\author{
Rong XU, ${ }^{a}$ Meng-Kwoon Sim, ${ }^{b}$ and Mei-Lin Go*,a \\ Department of Pharmacy ${ }^{a}$ and Department of Pharmacology, ${ }^{b}$ National University of Singapore, 10 Kent Ridge \\ Crescent, Republic of Singapore 119260. Received June 13, 1997; accepted October 13, 1997
}

\begin{abstract}
A series of tropinyl and piperidinyl esters was synthesized and evaluated for inhibitory activities on the endothelial muscarinic receptors of rat $\left(M_{3}\right)$ and rabbit $\left(M_{2}\right)$ aorta. Some of the esters (cyclohexylphenylglycolates and cyclohexylphenylpropionates) were found to be better antimuscarinic compounds than standard $M_{2}$ and $M_{3}$ inhibitors such as AFDX116 and 4-diphenylacetoxy- $N$-methylpiperidine (DAMP), with $\mathrm{p}_{\mathrm{EC}_{50}}$ values in the range of 8-9. A few esters were found to be more selective $M_{3}$ than $M_{2}$ inhibitors, but these tended to have low activities. The hydrophobic, electronic and steric characteristics of these esters were correlated with antimuscarinic activity by using appropriate parameters representing hydrophobicity (HPLC capacity factor, $\log k_{\mathrm{w}}$ ), size (molecular volume) and electronic character (Taft's polar substituent constant $\sigma^{*}$ and ${ }^{13} \mathrm{C}$ chemical shift difference $\Delta \delta$ ). Finally, 92\% of the $M_{2}$-inhibitory activities of the esters could be accounted for by the size and electronic character $\sigma^{*}$ of the side chain. In contrast, the $\mathrm{M}_{3}$-inhibitory activities of these esters were mainly attributed to the electronic nature $\left(\sigma^{*}, \Delta \delta\right)$ of the side chain, with good activity being associated with electron-withdrawing groups. Visualization of the comparative molecular field analysis (CoMFA) steric and electrostatic fields provided further confirmation of the structure-activity relationship (SAR) derived from traditional quantitative structure-activity relationship (QSAR) approaches.
\end{abstract}

Key words antimuscarinic activity; tropinyl esters; piperidinyl esters; quantitative structure-activity relationship; comparative molecular field analysis

The identification of multiple muscarinic receptors, pharmacologically classified into at least five subtypes $\left(\mathrm{M}_{1}-\mathrm{M}_{5}\right)$, has provided a strong impetus to the search for selective muscarinic ligands. ${ }^{1}$ This is based on the assumption that selective activation or interference with one of the muscarinic subtypes would result in novel therapeutic agents with reduced side effects. In addition, such agents might become improved tools for receptor classification. For example, $\mathbf{M}_{2}$-selective drugs might be useful in the treatment of cardiac disorders, ${ }^{2)}$ and possibly also in the therapy of Alzheimer's disease, by acting as antagonists at $\mathrm{M}_{2}$ autoreceptors in the central nervous system. ${ }^{3)}$ Selective antagonists at $\mathrm{M}_{3}$ receptors would result in improved management of respiratory disorders, such as chronic obstructive airway disease, ${ }^{4)}$ gastrointestinal disturbances such as irritable bowel syndrome ${ }^{5}$ and urinary tract disorders such as urge incontinence. ${ }^{6}$ However, few receptor-specific antagonists have been reported to date and those that are known mostly have modest selectivity. ${ }^{1)}$ This is not unexpected, as muscarinic receptor subtypes have about $65 \%$ similarity in their amino acid sequences, which makes it instrinsically difficult to find subtype-selective ligands. Therefore, novel muscarinic antagonists with increased subtype selectivity are of interest.

4-Diphenylacetoxy- $N$-methylpiperidine (DAMP) methobromide is a muscarinic ligand with a moderate selectivity for the $\mathrm{M}_{3}$ receptor subtype. ${ }^{7)}$ Various analogues of DAMP have been synthesized, but very few of these compounds have combined the high antagonistic potency of DAMP with improved selectivity. ${ }^{8-10)}$ In the present study, various esters related to DAMP have been synthesized with modifications at the acyl moiety and the aminoalcohol portion. The size of the acyl moiety has been varied to give groups which are smaller than (methyl, phenylacetate, phenylpropionate), equivalent to (benzilate,

* To whom correspondence should be addressed. diphenylpropionate) or bigger than (cyclohexylphenylacetate, cyclohexylphenylglycolate, cyclohexylphenylpropionate) the diphenylacetyl moiety present in DAMP. Concurrent hydrophobicity changes can be expected among the esters as a result of size variation. In addition, the inclusion of hydroxyl-containing side chains would result in changes in the electron density of the acyl grouping. As conformationally rigid DAMP analogues such as spiro-DAMP ${ }^{11)}$ generally show reduced selectivity, only modest conformational restraint was imposed upon the $N$-methylpiperidine ring of DAMP. This was achieved by the inclusion of an ethylene bridge to give the 8azabicyclo[3.2.1] octane (tropane) ring in the present series. Unlike DAMP, which carries a quaternary ammonium headgroup, the $N$-methylpiperidinyl and tropinyl esters were not quaternized to improve their distribution and transport properties. Some promising antagonists have been identified among these esters by functional pharmacological tests for $M_{2}$ and $M_{3}$ activity. The results show that high potency or selectivity can be achieved in appropriately modified DAMP analogues.

Chemistry The tropinyl and $N$-methylpiperidinyl esters were synthesized by standard procedures as shown in Chart 1. Two methods were employed, the first involving the reaction between the alcohol (tropine, $N$-methyl-4piperidinol) and acid chloride. ${ }^{12)}$ The tropinyl and $N$-methyl-4-piperidinyl esters of acetic acid (TM, NM), phenylacetic acid (TPA, NPA), 2-phenylpropionic acid (TPP, NPP), 2,2-diphenylacetic acid (TDPA, NDPA), 2,2-diphenylpropionic acid (TDPP, NDPP), cyclohexylphenylacetic acid (TCPA, NCPA) and cyclohexylphenylpropionic acid (TCPP, NCPP) were synthesized in this way. Except for cyclohexylphenylpropionic acid, the other acids were purchased commercially and converted to the acid chloride using thionyl chloride in good yields (70-84\%). Cyclohexylphenylpropionic acid was obtained

(C) 1998 Pharmaceutical Society of Japan 

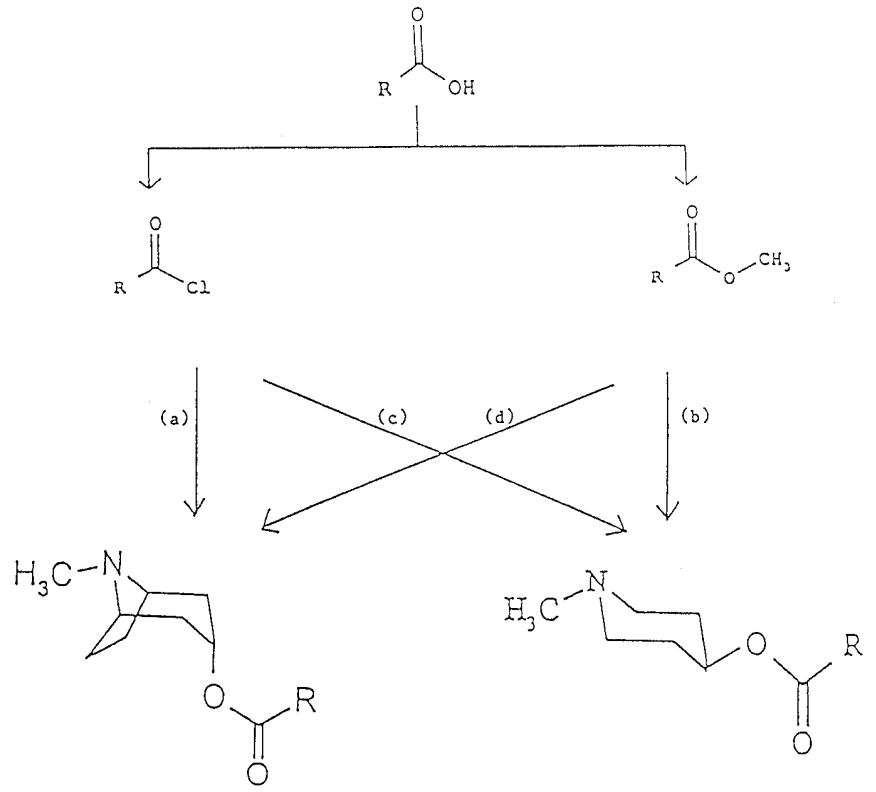

\begin{tabular}{|c|c|c|c|c|}
\hline$\underline{\mathrm{R}}$ & \multicolumn{2}{|c|}{ Tropinyl Ester } & \multicolumn{2}{|c|}{ Piperidinyl Ester } \\
\hline $\mathrm{PhCH}_{2-}^{-}$ & la & TPA & $1 \mathrm{~b}$ & NPA \\
\hline $\mathrm{Ph}\left(\mathrm{CH}_{3}\right) \mathrm{CH}-$ & $2 \mathrm{a}$ & TPP & $2 b$ & NPP \\
\hline$(\mathrm{Ph})_{2} \mathrm{CH}-$ & $3 a$ & TDPA & $3 \mathrm{~b}$ & NDPA \\
\hline$(\mathrm{Ph})_{2}\left(\mathrm{CH}_{3}\right) \mathrm{C}-$ & $4 a$ & TDPP & $4 \mathrm{~b}$ & NDPP \\
\hline$\left(\mathrm{Ph}_{2}\right)_{2}(\mathrm{OH}) \mathrm{C}-$ & $5 \mathrm{a}$ & TB & $5 b$ & NB \\
\hline $\mathrm{Ph}\left(\mathrm{C}_{6} \mathrm{H}_{11}\right) \mathrm{CH}_{2-}^{-}$ & $6 \mathrm{a}$ & TCPA & $6 \mathrm{~b}$ & NCPA \\
\hline $\mathrm{Ph}\left(\mathrm{C}_{6} \mathrm{H}_{11}\right)\left(\mathrm{CH}_{3}\right) \mathrm{C}-$ & $7 a$ & TCPP & $7 \mathrm{~b}$ & NCPP \\
\hline $\mathrm{Ph}\left(\mathrm{C}_{6} \mathrm{H}_{11}\right)(\mathrm{OH}) \mathrm{C}-$ & $8 \mathrm{a}$ & TCPG & $8 b$ & $\mathrm{NCPG}$ \\
\hline $\mathrm{CH}_{3}$ & $9 \mathrm{a}$ & TM & $9 b$ & NM \\
\hline
\end{tabular}

Chart 1. Reaction Sequence

a) Tropine, $100^{\circ} \mathrm{C} 4 \mathrm{~h}$. b) Tropine, NaOMe, heptane $5 \mathrm{~h}$. c) Methylpiperidinol, benzene, refluxing $24 \mathrm{~h}$. d) Methylpiperidinol, $\mathrm{NaOMe}$, heptane $15 \mathrm{~h}$.

from the alkaline hydrolysis of 2-cyclohexyl-2-phenylpropionitrile. ${ }^{13)}$ The latter was synthesized from the reaction between cyclohexylphenyl chloride and $\alpha$-methylbenzyl cyanide in the presence of potassium tert-butoxide. ${ }^{14}$ ) $\alpha$-Methylbenzyl cyanide formed a carbanion under these conditions which displaced the chloride atom of cyclohexylphenyl chloride to give the nitrile.

It was not possible to synthesize the remaining esters, tropinyl benzilate (TB), $N$-methyl-4-piperidinyl benzilate (NB), tropinyl cyclohexylphenylglycolate (TCPG) and $N$ methyl-4-piperidinyl cyclohexylphenylglycolate (NCPG), by the acid chloride method because the presence of the $\alpha-\mathrm{OH}$ group in these acids resulted in unwanted reactions with the acid chloride. Thus, these esters were synthesized by the transesterification method using the methyl ester of the carboxylic acid. ${ }^{15)}$ In this reaction, the alcoholic $\mathrm{OH}$ of tropine or $\mathrm{N}$-methyl-4-piperidinol was deprotonated by the strong methoxide base to form a nucleophile, which attacked the electron-deficient carbonyl carbon of methyl benzilate/methyl cyclohexylphenylglycolate. This was followed by loss of the methoxide anion (a good leaving group) as methanol. Removal of methanol from the reaction mixture by using a Dean-Stark apparatus further pushed the reaction equilibrium towards formation of the desired ester.

Cyclohexylphenylglycolic acid was obtained from the catalytic hydrogenation of benzilic acid under conditions $\left(80^{\circ} \mathrm{C}, 60 \mathrm{psi}, \mathrm{PtO}\right.$ as catalyst) described by Biel et al. ${ }^{16)}$ However, a mixture of partially hydrogenated acids was obtained. The mixture was converted to the methyl esters using methyl iodide and separated by column chromatography to give methyl cyclohexylphenylglycolate. The latter was transesterified with $N$-methylpiperidine or tropane to give the desired ester TCPG or NCPG, respectively.

Pharmacology The functional antimuscarinic activity of the esters were investigated on the endothelial muscarinic receptors $\left(\mathrm{M}_{3}\right)$ of the rat aorta ${ }^{17)}$ and the muscarinic receptors $\left(\mathrm{M}_{2}\right)$ of the de-endothelized rabbit aorta. ${ }^{18)}$ The esters inhibited acetylcholine (ACh)-induced relaxation of phenylepherine-contracted endotheliumintact rat aortic rings with the $\mathrm{p}_{\mathrm{EC}_{50}}\left(-\log \mathrm{EC}_{50}\right)$ values given in Table 1. They also inhibited the increase in the contractile response elicited by $\mathrm{ACh}$ to norepinepherineprecontracted endothelium-denuded rabbit aortic rings (Table 1). These actions were characteristic of muscarinic antagonists of the $\mathrm{M}_{2}$ and $\mathrm{M}_{3}$ receptor subtypes, which are present on the endothelium denuded rabbit and intact rat aortic rings, respectively. ${ }^{17,18)}$ The $\mathrm{p} K_{\mathrm{EC}_{50}}$ values of standard $\mathrm{M}_{2}$ (AFDX 116) and $\mathrm{M}_{3}$ receptor (DAMP) antagonists were also determined for comparison. For compounds which showed high antagonistic potency (TCPG, NCPG, TCPP, NCPP) and greater selectivity (NPA, TPP, NPP), the biological results were also expressed as $\mathrm{pA}_{2}$ values determined from Schild plots ${ }^{19)}$ constrained to slope-1.0, ${ }^{20)}$ as required by theory (Table 2).

The $\mathrm{pA}_{2}$ values of atropine and AFDX116 on the contraction response induced by $\mathrm{ACh}$ in endotheliumdenuded rabbit aortic rings were quite similar to those reported earlier. ${ }^{18)}$ The slopes of the Schild's plots for all the antagonists investigated on the endotheliumdenuded rabbit aortic rings did not vary significantly from $1 \quad(p<0.05)$, suggesting that these esters were competitive antagonists.

Similarly, the $\mathrm{pA}_{2}$ values of atropine, AFDX116 and DAMP on the relaxation response induced by $\mathrm{ACh}$ in endothelium-intact rat aortic rings were close to previously reported values. ${ }^{17)}$ The slopes of the Schild's plots for these antagonist esters were close to unity, with the exception of the cyclohexylphenylglycolate esters TCPG and NCPG, where the slopes were significantly greater than $1(p<0.05)$. The inhibitory effects of TCPG and NCPG were not reversed by washing. Neither was there a potentiation of inhibition when the ester was incubated together with methylbutyrate, a co-substrate of esterase. Such a potentiation had been previously observed for atropine and was attributed to the ability of methylbutyrate to saturate a putative esterase which hydrolysed atropine. ${ }^{17,21)}$ These observations suggested that TCPG and NCPG were stable esters, and that the gradient $(>1)$ of their Schild's plots was indicative of the non-competitive nature of the inhibition. Their $\mathrm{p} K_{\mathrm{B}}$ values were estimated by the method of Kenakin. ${ }^{22)}$

\section{Results and Discussion}

Other than the methyl esters (TM, NM), these esters demonstrated antagonistic activity at concentrations of less than $10^{-6} \mathrm{M}$. As seen from Table 1, a few esters (TB, NB, TCPG, NCPG, TCPP, NCPP) had $\mathrm{p} K_{\mathrm{EC}_{50}}$ values 
Table 1. Pharmacological and Physicochemical (Hydrophobic $\log K_{\mathrm{w}}$, Steric $\log \mathrm{MV}$, Electronic $\Delta \delta$ and $\sigma^{*}$ ) Data for Tropinyl and $N$ Methylpiperidinyl Esters

\begin{tabular}{|c|c|c|c|c|c|c|c|c|c|}
\hline Ester & $\mathrm{p} K_{\mathrm{EC}_{50}(\mathrm{M} 2)^{a)}}$ & $\mathrm{p} K_{\mathrm{EC}_{50}(\mathrm{M} 3)^{b)}}$ & $\mathrm{p} K_{\mathrm{EC}_{S 0}(\mathrm{M} 3) / \mathrm{EC}_{50}(\mathrm{M} 2)^{c)}}$ & $\sigma^{*}$ & $\Delta \delta$ & $\log k_{\mathrm{w}}$ & $\log M V$ & $\mathrm{~N}-3$ & $D^{d)}$ \\
\hline TPA & $5.26(0.21)$ & $5.97(0.11)$ & 0.71 & 0.215 & 0.226 & 1.55 & 2.38 & -1 & 0 \\
\hline TPP & $5.95(0.08)$ & $7.00(0.17)$ & 1.05 & 0.105 & 2.987 & 1.98 & 2.40 & -2 & 0 \\
\hline $\mathrm{TB}$ & $7.85(0.07)$ & $8.51(0.09)$ & 0.66 & 0.980 & 2.568 & 2.41 & 2.49 & -3 & 1 \\
\hline TDPA & $6.74(0.15)$ & $7.04(0.10)$ & 0.30 & 0.405 & 1.137 & 2.94 & 2.48 & -2 & 0 \\
\hline TDPP & $7.38(0.19)$ & $8.01(0.22)$ & 0.63 & 0.305 & 3.751 & 3.04 & 2.50 & -3 & 0 \\
\hline TCPG & $9.08(0.11)$ & $9.15(0.18)$ & 0.07 & 0.705 & 3.488 & 2.46 & 2.52 & -3 & 1 \\
\hline TCPA & $7.36(0.09)$ & $7.39(0.09)$ & 0.03 & 0.155 & 2.282 & 2.89 & 2.51 & -2 & 0 \\
\hline TCPP & $8.01(0.45)$ & $8.51(0.71)$ & 0.50 & 0.055 & 4.161 & 3.28 & 2.54 & -3 & 0 \\
\hline $\mathrm{TM}$ & $3.24(0.21)$ & $4.53(0.15)$ & 1.29 & 0 & 0 & - & 2.25 & 0 & 0 \\
\hline NPA & $4.40(0.09)$ & $5.65(0.23)$ & 1.25 & 0.215 & 0.066 & 1.36 & 2.33 & -1 & 0 \\
\hline NPP & $5.86(0.22)$ & $7.32(0.15)$ & 1.46 & 0.105 & 2.720 & 1.79 & 2.36 & -2 & 0 \\
\hline NB & $7.58(0.13)$ & $8.52(0.21)$ & 0.94 & 0.980 & 1.712 & 2.01 & 2.46 & -3 & 1 \\
\hline NDPA & $6.81(0.21)$ & $7.03(0.16)$ & 0.22 & 0.405 & 2.104 & 2.47 & 2.45 & -2 & 0 \\
\hline NDPP & $7.87(0.20)$ & $7.96(0.11)$ & 0.09 & 0.305 & 2.734 & 2.69 & 2.47 & -3 & 0 \\
\hline NCPG & $9.07(0.12)$ & $9.22(0.25)$ & 0.15 & 0.705 & 2.837 & 2.26 & 2.49 & -3 & 1 \\
\hline NCPA & $7.20(0.17)$ & $7.61(0.14)$ & 0.41 & 0.155 & 2.046 & 2.68 & 2.48 & -2 & 0 \\
\hline NCPP & $7.92(0.71)$ & $8.97(0.71)$ & 1.05 & 0.055 & 4.811 & 3.04 & 2.50 & -3 & 0 \\
\hline NM & $2.48(0.17)$ & $4.47(0.20)$ & 1.99 & 0 & 0 & - & 2.18 & 0 & 0 \\
\hline DAMP & $7.29(0.60)$ & $8.26(0.53)$ & 0.97 & - & - & - & - & - & - \\
\hline AF DX116 & $7.25(0.39)$ & $6.07(0.20)$ & -1.18 & - & - & - & - & - & - \\
\hline Atropine & $7.75(0.32)$ & $8.01(0.09)$ & 0.26 & 0.670 & 0.657 & 1.28 & 2.417 & -2 & 1 \\
\hline
\end{tabular}

a) Inhibitory activity of ester expressed as $-\log \mathrm{EC}_{50}\left( \pm\right.$ S.E.) for $n=9-12$ determinations, where $\mathrm{EC}_{50}$ is the concentration required to inhibit by $50 \%$ the ACh-induced contraction of norepinephrine-induced precontracted endothelium-denuded rabbit aortic rings. The muscarinic receptors in the denuded endothelium have been proposed to belong to the $\mathrm{M}_{2}$ subtype. ${ }^{18)}$ b) Inhibitory activity of ester expressed as $-\log \mathrm{EC}_{50}\left( \pm \mathrm{S}\right.$.E.) for $n=5-6$ determinations, where EC ${ }_{50}$ is the concentration required to inhibit by $50 \%$ the $\mathrm{ACh}$-induced relaxation of phenylepherine-induced precontracted endothelium (intact) of rat aortic rings. The muscarinic receptors in the intact endothelium are proposed to belong to the $\mathrm{M}_{3}$ subtype. ${ }^{17)}$ c) The higher the value, the greater the inhibitor activity of the ester for the $\mathrm{M}_{3}$ receptors of the endothelium-intact rat aorta. d) 0 or 1 indicates absence or presence of an $\mathrm{OH}$ group.

Table 2. $\mathrm{pA}_{2}$ Values and Slopes ${ }^{a}$ of Muscarinic Antagonists on the (i) Contraction Response Induced by $\mathrm{ACh}$ in Endothelium-Denuded Rabbit Aortic Rings $\left(\mathrm{M}_{2}\right)$ and the (ii) Relaxation Response Induced by ACh in Endothelium-Intact rabbit Aortic Rings $\left(\mathrm{M}_{3}\right)$

\begin{tabular}{|c|c|c|c|c|c|c|}
\hline \multirow{2}{*}{ Antagonist } & \multicolumn{3}{|c|}{$\mathrm{M}_{2}$} & \multicolumn{3}{|c|}{$\mathrm{M}_{3}$} \\
\hline & $\mathrm{pA}_{2}$ & Gradient $t^{b)}$ & $x$-intercep $t^{c)}$ & $\mathrm{pA}_{2}$ & Gradient $t^{b)}$ & $x$-intercept ${ }^{c)}$ \\
\hline NPA & 5.50 & $1.08(0.03)$ & $5.97(0.15)$ & 6.63 & $1.01(0.02)$ & $5.69(0.09)$ \\
\hline TPP & 6.14 & $1.07(0.03)$ & $6.54(0.16)$ & 7.16 & $1.00(0.07)$ & $7.12(0.44)$ \\
\hline NPP & 6.07 & $1.00(0.02)$ & $6.04(0.12)$ & 7.29 & $0.99(0.03)$ & $7.21(0.17)$ \\
\hline TCPP & 8.50 & $1.03(0.02)$ & $8.76(0.09)$ & 9.19 & $1.09(0.01)$ & $10.02(0.09)$ \\
\hline TCPG & 9.32 & $0.95(0.04)$ & $8.80(0.70)$ & $5.33^{d /}$ & $1.93(0.01)$ & $10.29(0.02)$ \\
\hline NCPG & 9.55 & $0.99(0.08)$ & $9.41(0.34)$ & $5.16^{d\}}$ & $1.98(0.01)$ & $10.20(0.02)$ \\
\hline NCPP & 8.38 & $0.96(0.04)$ & $8.24(0.32)$ & 9.59 & $1.08(0.01)$ & $9.95(0.02)$ \\
\hline Atropine & 8.10 & $0.96(0.03)$ & $7.79(0.20)$ & 8.36 & $1.19(0.15)$ & $9.95(0.68)$ \\
\hline DAMP & 7.73 & $1.03(0.03)$ & $7.97(0.20)$ & 8.75 & $0.99(0.07)$ & $8.65(0.37)$ \\
\hline AFDX 116 & 7.49 & $1.03(0.03)$ & $7.49(0.20)$ & 6.29 & $0.87(0.10)$ & $5.48(0.17)$ \\
\hline
\end{tabular}

a) Obtained from Schild regression using parallel response. b) Values in parentheses represent S.E. of gradient for no less than $n=12$. c) Values in parentheses represent S.E. of estimating $\log (\mathrm{Dr}-1)$ for no less than $n=12$. $d$ ) The $\mathrm{p} K_{\mathrm{B}}$ values of TCPG and NCPG were determined by the method of Kenakin ${ }^{22}$ and found to be 10.31 and 9.91 respectively.

which were higher than that of DAMP, the standard antagonist of $\mathrm{M}_{3}$ receptors. More of the esters (TB, NB, TDPP, NDPP, TCPA, TCPG, NCPG, TCPP, NCPP) were found to be better inhibitors (higher $\mathrm{p} K_{\mathrm{EC}_{50}}$ values) than the standard antagonist AFDX 116 at the $\mathrm{M}_{2}$ receptors of the endothelium-denuded rabbit aortic ring. The cyclohexylphenylpropionate (NCPP, TCPP) and cyclohexylphenylglycolate (NCPG, TCPG) esters were outstanding, as they had greater activities than the standard antagonists (DAMP, AFDX 116) at both $\mathrm{M}_{3}$ and $\mathrm{M}_{2}$ receptors.
A consideration of the $\mathrm{p} K_{\mathrm{EC}_{50}}$ values of the esters (including atropine) revealed some interesting trends. Firstly, there was a fairly good correlation between $\mathrm{M}_{3}$ and $\mathrm{M}_{2}$ activities, as revealed by the regression Eq. 1 and Fig. 1:

$$
\begin{gathered}
\mathrm{p} K_{\mathrm{EC}_{50}(\mathrm{M} 2)}=1.24( \pm 0.07) \mathrm{p}_{\mathrm{EC}_{50}(\mathrm{M} 3)}-2.45( \pm 0.56) \\
n=19, \quad r^{2}=0.94, \quad s=0.45, \quad F=277.70
\end{gathered}
$$

It was also observed that for a given acyl moiety, there was generally little difference between the $\mathrm{M}_{3}$-antagonist activities of the tropinyl and $N$-methylpiperidinyl esters. In contrast, for $\mathrm{M}_{2}$-antagonist activity, there were more examples of greater potency residing in the tropinyl ester than the $N$-methylpiperidinyl derivative (Table 1).

All the esters had greater activities at the $\mathrm{M}_{3}$ receptor. This was seen from the ratio of their $\mathrm{p} K_{\mathrm{EC}_{50}}$ values at $\mathrm{M}_{2}$ and $\mathrm{M}_{3}\left(\mathrm{p}_{\mathrm{EC}_{50}(\mathrm{M} 3) / \mathrm{EC}_{50}(\mathrm{M} 2)}\right)$. Unfortunately the more potent esters such as NCPG and TCPG did not show outstanding $\mathrm{M}_{3}$ selectivity. Such selectivity was observed only among the less potent esters such as NM, TM, NPA, TPP, NPP, and NCPP, which were more selective than DAMP.

Although many of the esters (phenylpropionates, cyclohexylphenylacetates, cyclohexylphenylpropionates, cyclohexylphenylglycolates) were racemates, they were not resolved into the optically pure forms in this study. This would be an interesting area for future research, as a recent report $^{23)}$ described stereoselectivity in the antimuscarinic activity of the methiodide salt of $N$-methylpiperidinyl cyclohexylphenylglycolate, with greater activity residing in the $\mathrm{R}$ isomer than the racemate.

In an attempt to understand the molecular characteristics of these esters which may influence the biological 


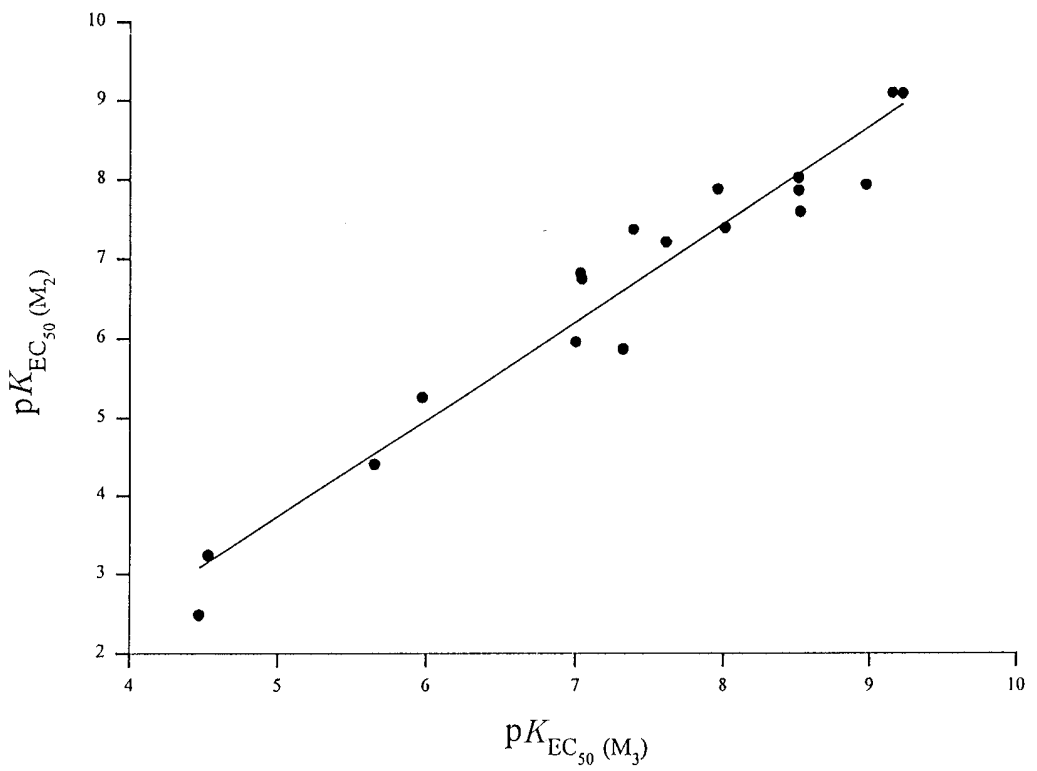

Fig. 1. Plot of $\mathrm{p} K_{\mathrm{EC}_{50}(\mathrm{M} 2)}$ versus $\mathrm{p} K_{\left.\mathrm{EC}_{50}(\mathrm{M} 3\}\right)}$ of Piperidinyl and Tropinyl Esters

activities, a quantitative structure-activity relationship (QSAR) study was carried out in which the $\mathrm{M}_{2}$ and $\mathrm{M}_{3}$ antagonistic activities $\left(\mathrm{p}_{\mathrm{EC}_{50}}\right)$ were correlated to parameters representing hydrophobicity ( $\log k_{\mathrm{w}}$, CLOGP), steric features (molecular volume, MV) and electronic character (Taft's polar substituent constant $\sigma^{*}$ for the group R in the acyl side chain $\mathrm{R}-\mathrm{CO}$ - and the ${ }^{13} \mathrm{C}$ chemical shift difference of the carbonyl carbon $\Delta \delta$ ). A good correlation $\left(r^{2}=0.83\right)$ was observed between the experimentally determined hydrophobicity values and those calculated using CLOGP. Thus, the experimentally determined hydrophobicity values were used for subsequent correlation studies.

A regression of $\mathrm{M}_{2}$ antagonist activity against the hydrophobic, steric or electronic parameter indicated that activity was best correlated to the size of the ester (Table 3). The regression Eq. 2 showed that $87 \%$ of $M_{2}$ antagonistic activity could be accounted for by the size of the ester alone.

$$
\begin{gathered}
\mathrm{p}_{\mathrm{EC}_{50}(\mathrm{M} 2)}=17.36( \pm 1.61) \log \mathrm{MV}-35.50( \pm 3.92) \\
n=19, \quad r^{2}=0.87, \quad s=0.66, \quad F=115.64
\end{gathered}
$$

The validity of this equation was further confirmed by its cross-validated $r^{2}\left(r_{\mathrm{cv}}^{2}=0.85\right)$. The value of $r_{\mathrm{cv}}^{2}$ is always lower than the conventional $r^{2}$ and an $r_{\mathrm{cv}}^{2}$ value greater than 0.5 is considered to indicate good predictive ability.

Poorer correlations were obtained with hydrophobicity or either electronic parameter $\left(\sigma^{*}\right.$ and $\left.\Delta \delta\right)$. The poor correlation with the hydrophobic parameter $\left(\log k_{\mathrm{w}}\right)$ was somewhat surprising, as lipophilicity had been noted to be important for muscarinic antagonism. ${ }^{24,25)}$

A similar observation was made for $\mathrm{M}_{3}$ antagonist activity. Size was far superior to hydrophobic or electronic parameters in accounting for activity (Table 3 ). Indeed, $78 \%$ of the observed variation in $\mathrm{p} K_{\mathrm{EC}_{50}(\mathrm{M} 3)}$ could be accounted by the $\log \mathrm{MV}$ parameter alone, which is slightly less than that observed for $\mathrm{p} K_{\mathrm{EC}_{50}(\mathrm{M} 2)}$.

In an attempt to improve the correlation, $\mathrm{p} K_{\mathrm{EC} 50}$ values were regressed in a stepwise manner against combinations
Table 3. Examples of QSAR Results for Inhibitory Activities of Esters $(n=19)$ at $\mathbf{M}_{2}$ and $\mathbf{M}_{3}$ Receptors of Rabbit Denuded $\left(\mathbf{M}_{2}\right)$ and Rat Intact $\left(\mathrm{M}_{3}\right)$ Aortic Endothelium

$r^{2} \quad r_{\mathrm{cv}}^{2} \quad \begin{gathered}\text { Standard } \\ \text { error of } \\ \text { estimate }\end{gathered} \quad F$-value

\begin{tabular}{lrrrr}
\hline $\mathrm{p} K_{\mathrm{EC} 50(\mathrm{M} 2)}$ & & & & \\
regressors & & & & \\
$\log \mathrm{MV}$ & 0.87 & 0.85 & 0.66 & 115.64 \\
$\log k_{\mathrm{w}}$ & 0.26 & -0.01 & 1.11 & 5.31 \\
$\sigma^{*}$ & 0.32 & 0.14 & 1.53 & 8.06 \\
$\Delta \delta$ & 0.51 & 0.34 & 1.291 & 17.98 \\
$\log \mathrm{MV}, \sigma^{*}$ & 0.92 & 0.89 & 0.56 & 84.86 \\
$\log k_{\mathrm{w}}, \sigma^{*}$ & 0.62 & 0.40 & 0.83 & 11.29 \\
$\sigma^{*}, \Delta \delta$ & 0.80 & 0.71 & 0.83 & 67.93 \\
$\mathrm{p} K_{\mathrm{EC}}$ & & & & \\
$\operatorname{regressors}$ & & & & \\
$\log \mathrm{MV}$ & 0.78 & 0.74 & 0.78 & 61.06 \\
$\log k_{\mathrm{w}}$ & 0.21 & -0.05 & 0.95 & 3.88 \\
$\sigma^{*}$ & 0.31 & 0.15 & 1.21 & 7.78 \\
$\Delta \delta$ & 0.62 & 0.52 & 0.90 & 27.65 \\
$\log \mathrm{MV}, \sigma^{*}$ & 0.83 & 0.77 & 0.62 & 36.16 \\
$\log k_{\mathrm{w}}, \sigma^{*}$ & 0.53 & 0.30 & 0.76 & 7.75 \\
$\sigma^{*}, \Delta \delta$ & 0.90 & 0.85 & 0.48 & 69.91 \\
$\mathrm{p} K_{\mathrm{EC}}$ & & & & \\
$\operatorname{regressors}\left(\mathrm{M} 3 \mathrm{C}_{50}(\mathrm{M} 2)\right.$ & & & & \\
$\log \mathrm{MV}$ & & & & \\
$\log k_{\mathrm{w}}$ & 0.63 & 0.55 & 0.34 & 28.77 \\
$\sigma^{*}$ & 0.15 & 0.14 & 0.42 & 2.55 \\
$\Delta \delta$ & 0.18 & -0.09 & 0.51 & 3.63 \\
$\log \mathrm{MV}, \sigma^{*}$ & 0.11 & -0.16 & 0.53 & 2.04 \\
$\log k_{\mathrm{w}}, \sigma^{*}$ & 0.64 & 0.47 & 0.35 & 14.21 \\
$\sigma^{*}, \Delta \delta$ & 0.28 & -0.15 & 0.40 & 2.66 \\
& 0.27 & -0.05 & 0.48 & 6.33
\end{tabular}

of independent variables. As there were only 19 esters (including atropine), the number of independent variables was restricted to two and then, only to variables which were truly independent of each other, as seen from the $r$ values given in the correlation matrix (Table 4). Stepwise multiple linear regression showed that the correlation to $\mathrm{M}_{2}$ antagonist activity was improved if size and the 
Table 4. Correlation ( $r$ ) Matrices for Independent Variables Used in Regression for $n=19$ Esters

\begin{tabular}{lcccccc}
\hline \hline & $\sigma^{*}$ & $\Delta \delta$ & $\mathrm{N}-3$ & $\log k_{\mathrm{w}}$ & $\log \mathrm{MV}$ & $D$ \\
\hline$\sigma^{*}$ & 1.000 & 0.046 & 0.524 & 0.230 & 0.407 & 0.900 \\
$\Delta \delta$ & 0.046 & 1.000 & 0.827 & 0.707 & 0.739 & 0.055 \\
$\mathrm{~N}-3$ & 0.524 & 0.827 & 1.000 & 0.596 & 0.899 & 0.429 \\
$\log k_{\mathrm{w}}$ & 0.230 & 0.707 & 0.596 & 1.000 & 0.853 & 0.300 \\
$\log \mathrm{MV}$ & 0.407 & 0.739 & 0.899 & 0.853 & 1.000 & 0.278 \\
$D$ & 0.900 & 0.055 & 0.429 & 0.300 & 0.278 & 1.00 \\
\hline
\end{tabular}

electronic character $\sigma^{*}$ of the ester were considered together (Eq. 3).

$$
\begin{gathered}
\mathrm{p} K_{\mathrm{EC}_{50}(\mathrm{M} 2)}=15.66( \pm 1.49) \log \mathrm{MV}+1.28( \pm 0.46) \sigma^{*}-31.81( \pm 3.57) \\
n=19, \quad r^{2}=0.92, \quad s=0.56, \quad F=84.86
\end{gathered}
$$

The cross-validated $r^{2}(0.89)$ of Eq. 3 is higher than that of Eq. $2\left(r_{\mathrm{cv}}^{2}=0.85\right)$. An electron-withdrawing group is desirable for good activity, but the contribution of $\sigma^{*}$ is small compared to log MV.

Of the various independent variables listed in Table 4, $\sigma^{*}$ was very well correlated to the dummy parameter $D$, which is either zero or 1, depending on whether an $\mathrm{OH}$ group is present or absent from the side chain. A large $\sigma^{*}$ value was invariably related to the presence of an $\mathrm{OH}$ group. The inductively electron-withdrawing effect of the oxygen atom in the $\mathrm{OH}$ group may be responsible for this correlation.

One would normally expect a good correlation between $\sigma^{*}$ and $N-3$, where $N$ is the number of hyperconjugable $\alpha \mathrm{C}-\mathrm{H}$ atoms. A large $N$ (maximum 3) should increase the electron-donating effect of the side chain due to hyperconjugation. It follows that a small $N$ would reduce the electron-donating effects and be associated with a larger $\sigma^{*}$. However, only a modest correlation was observed between $N-3$ and $\sigma^{*}$.

An improved correlation of $\mathrm{M}_{3}$ activity was observed when regression was done against a combination of two parameters. As shown in Eq. 4, $90 \%$ of $\mathrm{M}_{3}$ antagonist activity could be accounted for by two electronic parameters of the acyl side chain $\left(\sigma^{*}\right.$ and $\left.\Delta \delta\right)$. The $r_{\mathrm{cv}}^{2}(0.85$, 1 principal component) further confirmed the predictive utility of this model.

$$
\begin{gathered}
\mathrm{p}_{\mathrm{EC}_{50}(\mathrm{M} 3)}=2.47( \pm 0.36) \sigma^{*}+0.78( \pm 0.08) \Delta \delta+4.98( \pm 0.23) \\
n=19, \quad r^{2}=0.90, \quad s=0.48, \quad F=69.91
\end{gathered}
$$

As shown from the coefficients of $\sigma^{*}$ and $\Delta \delta$ in Eq. 4 , $\sigma^{*}$ plays a more significant role than $\Delta \delta$ in determining activity. An electron-withdrawing sidechain is also favourable for activity. $\sigma^{*}$ and $\Delta \delta$ are poorly correlated to each other (Table 4); $\sigma^{*}$ is an indirect measure of the electron-withdrawing capacity of $\mathrm{R}$ in the side chain $\mathrm{R}-\mathrm{C}(\mathrm{O})$ while $\Delta \delta$ gives a direct measure of the electronic effect of R. However, $\Delta \delta$ does not give the same level of mechanistic insight as $\sigma^{*}$, and variations in $\Delta \delta$ have been attributed to a complex mixture of steric and electronic factors. ${ }^{26)}$ In the case of the present series of esters, $\Delta \delta$ of R showed a good correlation to size (log MV) and $N-3$ (Table 4). The reliance of antagonistic activity on electronic character of the side chain alone is somewhat unusual, as other reports had stressed the importance of lipophilicity ${ }^{24)}$ or a combination of lipophilic and electronic character. ${ }^{27)}$

TCPG and NCPG were the most potent antagonists of both $\mathrm{M}_{2}$ and $\mathrm{M}_{3}$ activity. Their high $\mathrm{M}_{2}$ antagonist activity could be readily accounted for by their large size and strongly electron-withdrawing side chain (large $\sigma^{*}$ ). Comparison with the cyclohexylphenylpropionates and benzilates, which had either large volumes (TCPP, NCPP) or strongly electron-withdrawing side chains (TB, NB), but not both, clearly emphasized the necessity of esters having both characteristics for good $\mathrm{M}_{2}$-antagonistic activity.

Similarly, the potent $\mathrm{M}_{3}$ antagonist activity of TCPG and NCPG could be readily explained by the strongly electron-withdrawing capacity of the side chains and the large $\Delta \delta$ associated with them. As stated earlier, strong electron-withdrawing effects (large $\sigma^{*}$ ) were associated with the $\mathrm{OH}$-containing side chains present in the benzilates and cyclohexylphenylglycolates. This may be traced to the inductive electron-withdrawing effect of oxygen in $\mathrm{OH}$. Interestingly, benzilates which have large $\sigma^{*}$, but low $\Delta \delta$ values were less potent $\mathrm{M}_{3}$ antagonists.

Many investigators have noted that esters with an $\mathrm{OH}$ group in the acyl side chain were generally associated with greater antimuscarinic activity. Recanatini et al. ${ }^{10)}$ proposed that the presence of the $\mathrm{OH}$ group might influence the conformation of the molecule so that the group interacted with additional binding sites at the receptor. Other investigators pointed out that the increase in activity was not related to the hydrophilicity of the $\mathrm{OH}$ group, but rather to its ability to interact by electrostatic interaction or hydrogen bonding to the receptor. ${ }^{27)}$ Our observations that $\mathrm{OH}$-containing side chains possessed large $\sigma^{*}$ values suggest that the activity-enhancing effects of these side chains are related to their electron density and indirectly to the ability of the $\mathrm{OH}$ group to interact as an H-bond donor or acceptor with the receptor environment.

With few exceptions, greater $\mathrm{M}_{3}$ selectivity was observed in the $N$-methylpiperidinyl esters (Table 1). The esters NPA, TPP, NPP and NCPP had greater $\mathrm{M}_{3}$ selectivities than DAMP. Regression of various parameters against the ratio $\mathrm{p} K_{\mathrm{EC}_{50}(\mathrm{M} 3) / \mathrm{EC}_{50}(\mathrm{M} 2)}$ showed that the variation in ratio was best accounted for by Eq. 5. About $63 \%$ of the observed variation in $\mathrm{M}_{2} / \mathrm{M}_{3}$ activities may be attributed to the size $(\log \mathrm{MV})$ of the ester alone. Although a combination of $\log \mathrm{MV}$ and $\sigma^{*}$ gave a model with almost the same $r^{2}$ as $\log \mathrm{MV}$ alone, there was a sharp decline in the cross-validated $r_{\mathrm{cv}}^{2}$. Thus, the model given in Eq. 5 $\left(r_{\mathrm{cv}}^{2}=0.55\right)$ is still preferred.

$$
\begin{gathered}
\mathrm{p} K_{\mathrm{EC}_{50}(\mathrm{M} 3) / \mathrm{EC}_{50}(\mathrm{M} 2)}=-4.49( \pm 0.84) \log \mathrm{MV}+11.60( \pm 2.03) \\
n=19, \quad r^{2}=0.63, \quad s=0.34, \quad F=28.77
\end{gathered}
$$

The negative coefficient of the size parameter $\log \mathrm{MV}$ indicated that smaller esters (such as the $N$-methylpiperidinyl esters NPP, NPA) should give rise to greater selectivity at $M_{3}$ receptors. Unfortunately, esters with good selectivity (e.g. NPA) would not demonstrate good $\mathrm{M}_{3}$-antagonistic activity, as selectivity and activity have 
Table 5. Summary of CoMFA Models ${ }^{a)}$

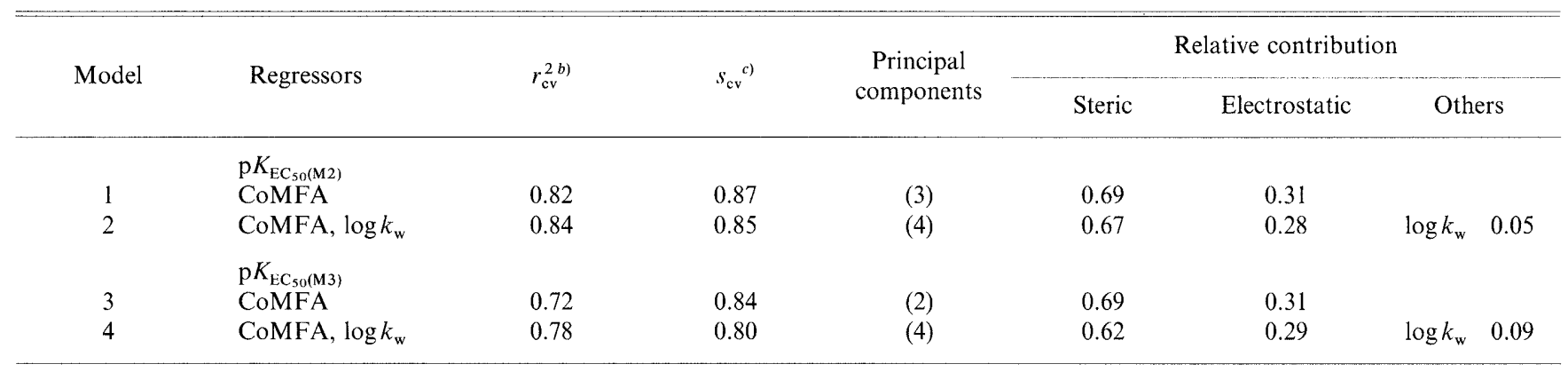

a) Modified biological data for chiral esters (see text). b) Cross-validated $r^{2}$ of model. c) Cross-validated standard error of model.

opposing steric requirements.

In addition to conventional QSAR approaches, a comparative molecular field analysis (CoMFA) was performed on the same set of 19 esters. The advantage of such an analysis is that it allows visualization of electrostatic and steric regions in three dimensional (3D)-space which are favorable or unfavorable for molecular interaction. The energy-minimized conformations of the compounds were aligned by the distance comparison (DISCO) module in SYBYL 6.2 (Tripos Inc., St Louis, MO 63144) and the resulting best model was subjected to CoMFA. In order to assess how well the model predicted activity, each predictive value was cross-validated using initially 5 components, before subsequently determining the optimum number of components. The statistical evaluation is shown in Table 5.

Because of the chiral character of some esters (TPP, NPP, TCPP, NCPP, TCPG, NCPG), the biological data of these esters were treated in two ways. Firstly, the biological activities of the chiral esters were assigned the experimentally determined values obtained from the functional assays and secondly, the activities of these esters were increased by $0.30 \mathrm{pK}_{\mathrm{EC}_{50}}$ units, based on the assumption that activity resides in the enantiomer with the active conformation. CoMFA was carried out using either set of data and it was found that both gave qualitatively similar results, although small numerical differences were detected in the validation parameters. The final results reported were those obtained using the modified values.

It can be seen that the CoMFA model 1 describing $\mathrm{M}_{2}$ activity showed good predictive ability $\left(r_{\mathrm{cv}}^{2}>0.5\right)$. As the CoMFA fields are essentially steric and electrostatic in nature, a hydrophobic parameter $\log k_{\mathrm{w}}$ was included as another variable. As shown in Table 5, the resulting CoMFA model 2 which included the hydrophobic parameter was no better than model 1 , since inclusion of the additional parameter did not decrease the crossvalidated standard error by more than $5 \% .{ }^{28)}$ Thus, the simpler model (1) is preferred. In contrast, in the case of $\mathrm{M}_{3}$ activity, the initial CoMFA model (3) was improved upon incorporation of the lipophilic parameter. This is evident when the statistical parameters $r_{\mathrm{cv}}^{2}$ and $s_{\mathrm{cv}}$ of models 3 and 4 are compared.

The CoMFA results for $\mathrm{M}_{2}$ activity reflect and confirm the findings obtained with traditional QSAR approaches. Thus, the strong correlation between $\mathrm{M}_{2}$ activity and the size of the ester (Eq. 3) is reflected in model 1, in which the steric contribution to the CoMFA field was found to be $69 \%$. In contrast, the CoMFA results for $\mathrm{M}_{3}$ activity assigned more weight to the steric parameter (models 3,4 ), which was not apparent in the best-fit equation for $\mathbf{M}_{3}$ activity (Eq. 4), where only electrostatic parameters ( $\sigma^{*}$, $\Delta \delta$ ) were variables. A possible explanation is the high correlation between $\Delta \delta$ and $\log \mathrm{MV}$ (Table 4 ), and the latter is reflected in the steric component of CoMFA. Although the CoMFA model 3 for $\mathrm{M}_{3}$ activity was improved on addition of $\log k_{\mathrm{w}}$ as an additional variable, the contribution of the hydrophobic component remains small.

In order to visualize the information content of the best 3D-QSAR models 1 and 4, CoMFA contour maps were generated. The steric field map is described by green and yellow polyhedra which are equivalent to regions of space around the molecules where increases in steric bulk enhance (green) or diminish (yellow) muscarinic antagonist activity. The CoMFA electrostatic contour maps are described by blue and red polyhedra which are equivalent to regions where high electron density (i.e., negative charge or polarity) within the molecule diminishes (blue) or enhances (red) activity.

The CoMFA steric and electrostatic fields of models 1 and 4 for $M_{2}$ and $M_{3}$ activities respectively were consistent with the known SAR and showed many similarities. The steric contours of both models showed large yellow and smaller green zones interspersed around the acyl moiety. The high $\mathrm{M}_{2} / \mathrm{M}_{3}$ activities of TCPG and NCPG arose from the projection of the cyclohexyl and $\mathrm{OH}$ groups into the green zone (Fig. 2a, 2b). Less active esters such as TM, NM, TPA, NPA either occupied sterically unfavorable yellow zones or did not occupy the sterically favoured green zones.

Both models showed smaller electrostatic contours compared to steric contours. There was a larger red zone present in model 4 for $\mathrm{M}_{3}$ activity. Interestingly, the red zones in both models 1 and 4 coincided in part with the sterically favorable green zones. It was observed that the oxygen atom of the OH group in NCPG and TCPG is projected towards the red zone present in models 1 and 4 , which is an electrostatically favorable interaction. On the other hand, the oxygen atom of $\mathrm{OH}$ in the less active benzilates is projected away from this red zone (Fig. 3a, $3 b)$. This may account for the lower $\mathbf{M}_{3}$-antagonistic activities of the benzilates. 

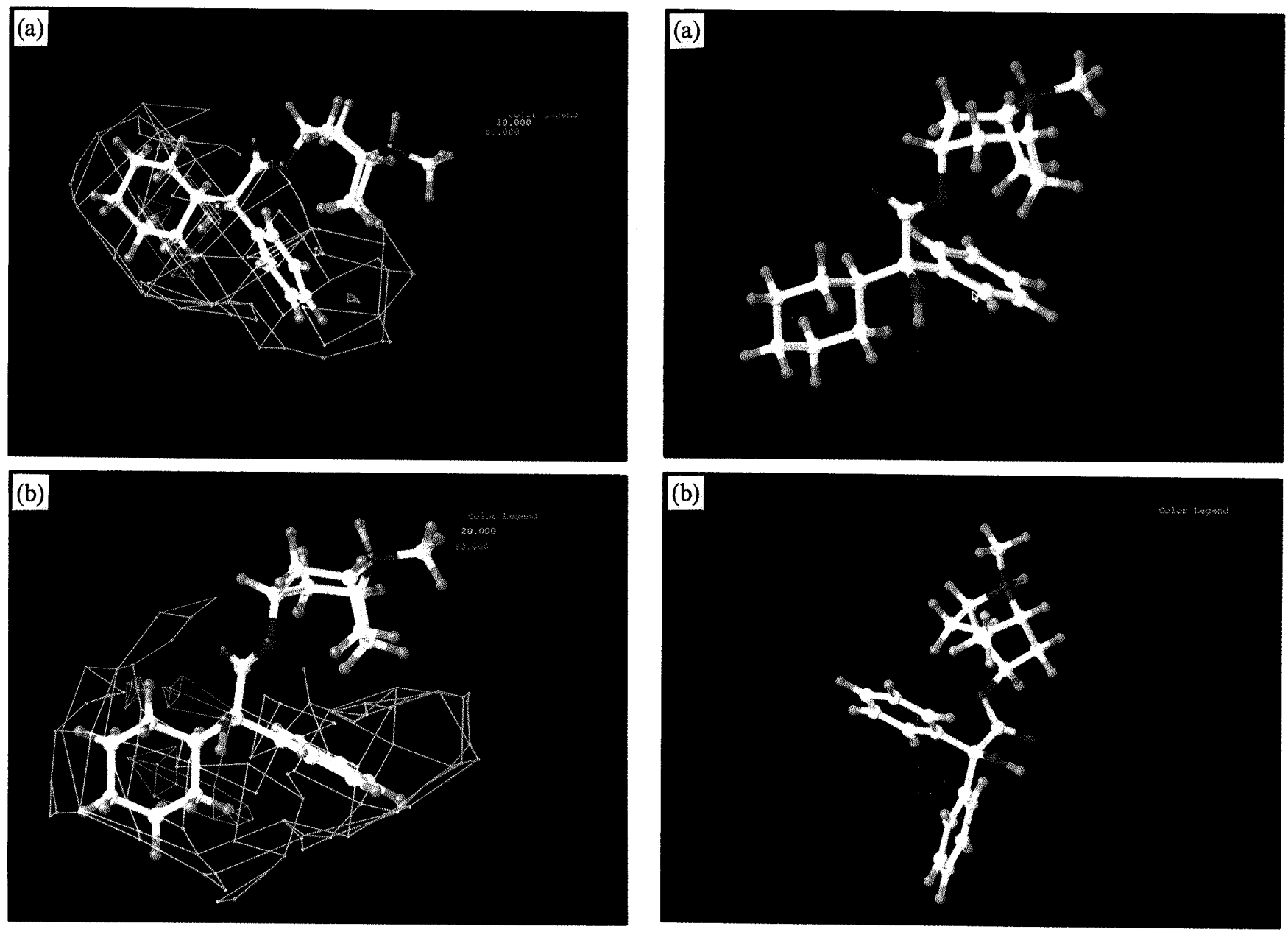

Fig. 2. Steric Contour Maps of the (a) CoMFA Model 1 (Table 5, $r_{\mathrm{cv}}^{2}=0.82$ ) and (b) CoMFA Model 4 (Table 5, $r_{\mathrm{cv}}^{2}=0.78$ ) Showing the Orientation of the Highly Active Analogue, TCPG

\section{Conclusion}

In conclusion, fairly simple structural modifications of the standard $\mathrm{M}_{3}$-antagonist DAMP have yielded esters with greater antagonist potency or $\mathrm{M}_{3}$ selectivity than DAMP itself. The SAR of these esters were evaluated by QSAR and CoMFA. Both methods produced acceptable models, as seen from their $r_{\mathrm{cv}}^{2}$ values. In addition, the QSAR and CoMFA models for muscarinic antagonist activity were found to be quite consistent with each other. Structural features of the esters essential for the antagonism of the $M_{2}$ and $M_{3}$ receptors of the denuded endothelium of the rabbit aorta and the intact rat aorta, respectively, were found to differ. For $\mathbf{M}_{2}$-antagonist activity, the size and electron-withdrawing character of the acyl side chain seemed most important. In contrast, for $\mathbf{M}_{3}$ antagonist activity, the electronic character (assessed in this study by $\Delta \delta$ and $\sigma^{*}$ ) of the side chain was more important.

\section{Experimental}

1. Synthesis Melting points were taken on a Gallenkamp apparatus and are uncorrected. Infrared (IR) spectra were recorded with a Philips PU 9624 FTIR spectrometer in pressed $\mathrm{KBr}$ discs (solids) or neat (liquids). ${ }^{1} \mathrm{H}-\mathrm{NMR}$ spectra were recorded on a Bruker ACF $(300 \mathrm{MHz})$ spectrometer. Chemical shifts were reported as $\delta \mathrm{ppm}$ relative to tetramethylsilane (TMS). Nominal and accurate masses were determined on a VG Micromass $7035 \mathrm{E}$ mass spectrometer (with chemical ionization).

Fig. 3. Electrostatic Contour Maps of the CoMFA Model 4 (Table 5, $r_{\mathrm{cv}}^{2}=0.78$ ), Showing (a) the Projection of the $\mathrm{OH}$ Group of the Highly Active Analogue, TCPG, into the Red Zone and (b) the Absence of such an Orientation in the Less Active Analogue, TB

Chromatographic separations were performed with Merck 60-200 mesh silica gel. Elemental analyses, unless indicated, were in agreement with calculated values within $\pm 0.4 \%$.

The physical data of the esters are given in Table 6 . The syntheses of TPP, NPP, TDPP, NDPP, TCPA, NCPA, TCPP, NCPP and TCPG have not previously been reported.

General Method for the Preparation of Acid Chloride A solution of thionyl chloride $(0.1 \mathrm{~mol}, 6.2 \mathrm{ml})$ in dry benzene was added dropwise to a stirred solution of the carboxylic acid $(0.04 \mathrm{~mol})$ in dry benzene. The mixture was then refluxed for $4-8 \mathrm{~h}$, after which benzene and excess thionyl chloride were removed by distillation. Fresh dry benzene $(4 \times 60 \mathrm{ml})$ was added to the mixture and the process was repeated to remove traces of thionyl chloride. The acid chloride was obtained by distillation under reduced pressure, with the exception of 2,2-diphenylacetyl chloride, which was a solid $\left(\mathrm{mp} 53^{\circ} \mathrm{C}\right)\left(\text { lit. } 51-53^{\circ} \mathrm{C}\right)^{29)}$ and was recrystallized using hexane.

General Method for the Synthesis of Esters TPA, TPP, TDPA, TDPP, TCPA and TCPP from Tropine and Acid Chloride Tropine $(0.01 \mathrm{~mol}$, $1.41 \mathrm{~g})$ and acid chloride $(0.02 \mathrm{~mol})$ were stirred together in an oil bath $\left(100^{\circ} \mathrm{C}\right)$ for $4 \mathrm{~h}$. The mixture was cooled, then water was added and strong ammonia solution was added dropwise until alkalinity was reached. The aqueous solution was extracted with diethyl ether and the ethereal layer was washed with water, dried using anhydrous $\mathrm{Na}_{2} \mathrm{SO}_{4}$ and evaporated in vacuo. The residue was dried and converted to the hydrochloride salt using ethereal $\mathrm{HCl}$. Recrystallization of the $\mathrm{HCl}$ salt was carried out using absolute ethanol and dry ether.

General Method for the Synthesis of Esters NPA, NPP, NDPA, NDPP, NCPA and NCPP from $\mathbf{N}$-Methyl-4-piperidinol and Acid Chloride A solution of the acid chloride $(0.019 \mathrm{~mol})$ in dry benzene was added dropwise to a stirred solution of $N$-methyl-4-piperidinol $(0.014 \mathrm{~mol}, 1.7 \mathrm{~g})$ in dry pyridine $(4 \mathrm{ml})$. The mixture was refluxed for $24 \mathrm{~h}$, after which 
Table 6. Physical Data for Synthesized Compounds

\begin{tabular}{|c|c|c|c|c|c|c|}
\hline Compound & $\%$ Yield & $\mathrm{mp}\left({ }^{\circ} \mathrm{C}\right)^{a)}$ & $\begin{array}{l}\text { Elemental } \\
\text { analysis }^{b)}\end{array}$ & $\begin{array}{l}\text { Accurate } \\
\text { mass }^{c)}\end{array}$ & $\operatorname{IR}\left(\mathrm{cm}^{-1}\right)^{d)}$ & ${ }^{1} \mathrm{NMR}(\delta \mathrm{ppm})^{e)}$ \\
\hline 1a (TPA) & 61 & $\begin{array}{l}197-199 \\
\left.\text { (lit. }^{30)} 197-198.5\right)\end{array}$ & $\mathrm{C}, \mathrm{H}$ & $\begin{array}{l}259.1566 \\
\left(\mathrm{C}_{16} \mathrm{H}_{21} \mathrm{NO}_{2}\right. \\
=259.1572)\end{array}$ & 1730.07 & $\begin{array}{l}\left(\mathrm{CH}_{3} \mathrm{OD}\right) 7.16(\mathrm{~s}, 5 \mathrm{H}, \text { aryl } \mathrm{H}), 4.93(\mathrm{t}, \mathrm{1H}, \mathrm{C} 3-\mathrm{H}) \\
3.63\left(\mathrm{~s}, 2 \mathrm{H}, \mathrm{Ar}-\mathrm{CH}_{2}-\mathrm{C}\right), 2.70\left(\mathrm{~s}, 3 \mathrm{H}, \mathrm{N}-\mathrm{CH}_{3}\right) \\
1.78-3.30(\mathrm{~m}, 8 \mathrm{H}, \mathrm{C} 2-\mathrm{H}, \mathrm{C} 4-\mathrm{H}, \mathrm{C} 6-\mathrm{H}, \mathrm{C}-\mathrm{H})\end{array}$ \\
\hline 1b (NPA) & 30 & $\begin{array}{l}178-179 \\
\left(\text { lit. }^{30)} 177.3-178.2\right)\end{array}$ & $\mathrm{C}, \mathrm{H}$ & - & 1738.36 & $\begin{array}{l}\left(\mathrm{DMSO}-d_{6}\right) 7.26-7.36(\mathrm{~m}, 5 \mathrm{H}, \text { aryl } \mathrm{H}), 4.90(\mathrm{~s}, 1 \mathrm{H}, \\
\mathrm{C} 4-\mathrm{H}), 3.69\left(\mathrm{~s}, 2 \mathrm{H},-\mathrm{CH}_{2}-\right), 3.16-3.35(\mathrm{~m}, 4 \mathrm{H}, \mathrm{C} 2-\mathrm{H}, \\
\left.\mathrm{C} 6-\mathrm{H}, \mathrm{CH}_{2}\right), 2.68\left(\mathrm{~s}, 3 \mathrm{H}, \mathrm{N}-\mathrm{CH}_{3}\right), 1.83-2.50(\mathrm{~m}, 4 \mathrm{H} \text {, } \\
\mathrm{C} 3-\mathrm{H}, \mathrm{C} 5-\mathrm{H})\end{array}$ \\
\hline 2a (TPP) & 70 & $180-183$ & $\mathrm{C}, \mathrm{H}$ & $\begin{array}{l}273.1728 \\
\left(\mathrm{C}_{17} \mathrm{H}_{23} \mathrm{NO}_{2}\right. \\
=273.1729)\end{array}$ & 1719.08 & $\begin{array}{l}\left(\mathrm{CH}_{3} \mathrm{OD}\right) 7.15(\mathrm{~s}, 5 \mathrm{H}, \text { aryl H}), 4.89(\mathrm{t}, 1 \mathrm{H}, \mathrm{C} 3-\mathrm{H}) \\
3.63\left(\mathrm{q}, 1 \mathrm{H}, \mathrm{Ar}-\mathrm{CH}-\mathrm{CH}_{3}\right), 3.27-3.30(\mathrm{~m}, 2 \mathrm{H}, \mathrm{Cl}-\mathrm{H}, \\
\mathrm{C} 5-\mathrm{H}), 2.67\left(\mathrm{~s}, 3 \mathrm{H}, \mathrm{N} \mathrm{CH}_{3}\right), 1.43(\mathrm{~d}, 3 \mathrm{H}, \\
\left.\mathrm{Ar}-\mathrm{CH}-\mathrm{CH}_{3}\right)\end{array}$ \\
\hline $\mathbf{2 b}(\mathrm{NPP})$ & 24 & $187-189$ & $\mathrm{C}, \mathrm{H}, \mathrm{N}$ & $\begin{array}{l}247.1569 \\
\left(\mathrm{C}_{15} \mathrm{H}_{21} \mathrm{NO}_{2}\right. \\
=247.1572)\end{array}$ & 1721.01 & $\begin{array}{l}\left(\text { DMSO- } d_{6}\right) 7.23-7.36(\mathrm{~m}, 5 \mathrm{H}, \text { aryl } \mathrm{H}), 4.89(\mathrm{~s}, 1 \mathrm{H} \\
\mathrm{C} 4-\mathrm{H}), 2.64\left(\mathrm{~s}, 3 \mathrm{H}, \mathrm{N}-\mathrm{CH}_{3}\right), 1.73-3.39(\mathrm{~m}, 8 \mathrm{H}, \\
\text { piperidinyl } \mathrm{H}), 1.39-1.42\left(\mathrm{~d}, 3 \mathrm{H}, \mathrm{Ar}-\mathrm{CH}-\mathrm{CH}_{3}\right) \\
1.03-1.10\left(\mathrm{q}, 1 \mathrm{H}, \mathrm{Ar}-\mathrm{CH}-\mathrm{CH}_{3}\right)\end{array}$ \\
\hline 3a (TDPA) & 32 & $\begin{array}{l}217-220 \\
\left(\text { lit. }^{30)} 213.5-214.2\right)\end{array}$ & $\mathrm{C}, \mathrm{H}, \mathrm{N}$ & $\begin{array}{l}335.1881 \\
\left(\mathrm{C}_{22} \mathrm{H}_{25} \mathrm{NO}_{2}\right. \\
=335.1885)\end{array}$ & 1727.00 & $\begin{array}{l}\left(\mathrm{DMSO}-d_{6}\right) 7.23-7.36(\mathrm{~m}, 10 \mathrm{H}, \text { aryl H) } \\
(\mathrm{t}, 1 \mathrm{H}, \mathrm{C} 3-\mathrm{H}), 3.69(\mathrm{~s}, 1 \mathrm{H},-\mathrm{CH}-), 2.56(\mathrm{~s}, 3 \mathrm{H} \\
\left.\mathrm{N}-\mathrm{CH}_{3}\right), 1.47-3.35(\mathrm{~m}, 10 \mathrm{H}, \mathrm{Cl}-\mathrm{H}, \mathrm{C} 2-\mathrm{H}, \mathrm{C} 4-\mathrm{H} \\
\mathrm{C} 5-\mathrm{H}, \mathrm{C} 6-\mathrm{H}, \mathrm{C} 7-\mathrm{H})\end{array}$ \\
\hline 3b (NDPA) & 35 & $\begin{array}{l}161-162 \\
\left(\text { lit. }^{30)} 135.5-137.0\right)\end{array}$ & $\mathrm{C}, \mathrm{H}, \mathrm{N}$ & $\begin{array}{l}309.1732 \\
\left(\mathrm{C}_{20} \mathrm{H}_{23} \mathrm{NO}_{2}\right. \\
=309.1729)\end{array}$ & 1730.65 & $\begin{array}{l}\left(\mathrm{DMSO}-d_{6}\right) 7.23-7.36(\mathrm{~m}, 10 \mathrm{H}, \text { aryl H}), 5.17(\mathrm{~s}, 1 \mathrm{H}, \\
\mathrm{C} 4-\mathrm{H}), 3.20-3.31\left(\mathrm{~m}, 4 \mathrm{H}, \mathrm{C} 2-\mathrm{H}, \mathrm{C} 6-\mathrm{H},-\mathrm{CH}_{2}-\right), 3.66 \\
(\mathrm{~s}, 1 \mathrm{H}, \mathrm{CH}), 3.34\left(\mathrm{~s}, 3 \mathrm{H}, \mathrm{N}-\mathrm{CH}_{3}\right), 1.14-1.18(\mathrm{~m}, 4 \mathrm{H}, \\
\mathrm{C} 3-\mathrm{H}, \mathrm{C} 5-\mathrm{H})\end{array}$ \\
\hline $4 a(T D P P)$ & 69 & $127-129$ & $\mathrm{C}, \mathrm{H}, \mathrm{N}$ & $\begin{array}{l}349.2042 \\
\left(\mathrm{C}_{23} \mathrm{H}_{27} \mathrm{NO}_{2}\right. \\
=349.2041)\end{array}$ & 1713.29 & $\begin{array}{l}\left(\mathrm{DMSO}-d_{6}\right) 7.19-7.40(\mathrm{~m}, 10 \mathrm{H}, \text { aryl H)}, 5.05-5.06 \\
(\mathrm{t}, 1 \mathrm{H}, \mathrm{C} 3-\mathrm{H}), 3.36-3.48(\mathrm{~m}, 2 \mathrm{H}, \mathrm{C} 1-\mathrm{H}, \mathrm{C} 5-\mathrm{H}), 2.60 \\
\left(\mathrm{~s}, 3 \mathrm{H}, \mathrm{N}-\mathrm{CH}_{3}\right), 1.93\left(\mathrm{~s}, 3 \mathrm{H}, \mathrm{Ar}-\mathrm{C}-\mathrm{CH}_{3}\right), 1.79-2.60 \\
(\mathrm{~m}, 4 \mathrm{H}, \mathrm{C} 6-\mathrm{H}, \mathrm{C}-\mathrm{H}), 1.06-1.42(\mathrm{~m}, 4 \mathrm{H}, \mathrm{C} 2-\mathrm{H} \\
\mathrm{C} 4-\mathrm{H})\end{array}$ \\
\hline $4 b$ (NDPP) & 25 & $128-130$ & $\mathrm{C}, \mathrm{H}, \mathrm{N}$ & $\begin{array}{l}323.1879 \\
\left(\mathrm{C}_{21} \mathrm{H}_{25} \mathrm{NO}_{2}\right. \\
=323.1885)\end{array}$ & 1728.72 & $\begin{array}{l}\left(\mathrm{DMSO}-d_{6}\right) 7.21-7.33(\mathrm{~m}, 10 \mathrm{H} \text {, aryl } \mathrm{H}), 5.15(\mathrm{~s}, 1 \mathrm{H} \text {, } \\
\mathrm{C} 4-\mathrm{H}), 2.63\left(\mathrm{~s}, 3 \mathrm{H}, \mathrm{N}-\mathrm{CH}_{3}\right) 1.72-3.41(\mathrm{~m}, 11 \mathrm{H}, \\
\left.\text { piperidinyl } \mathrm{H}, \mathrm{Ar}-\mathrm{C}-\mathrm{CH}_{3}\right)\end{array}$ \\
\hline $5 \mathbf{a}(\mathrm{TB})$ & 45 & $\begin{array}{l}242-243 \\
\text { (lit. }{ }^{28)} 239-240 \text { ) }\end{array}$ & $\mathrm{C}, \mathrm{H}, \mathrm{N}$ & $\begin{array}{l}351.1829 \\
\left(\mathrm{C}_{22} \mathrm{H}_{25} \mathrm{NO}_{3}\right. \\
=351.1834)\end{array}$ & 1733.05 & $\begin{array}{l}\left(\mathrm{DMSO}-d_{6}\right) 7.28-7.37(\mathrm{~m}, \mathrm{l} 0 \mathrm{H}, \text { aryl } \mathrm{H}), 5.05(\mathrm{t}, 1 \mathrm{H}, \\
\mathrm{C} 3-\mathrm{H}), 2.52\left(\mathrm{~s}, 3 \mathrm{H}, \mathrm{N}-\mathrm{CH}_{3}\right), 1.45-1.85(\mathrm{~m}, 8 \mathrm{H}, \\
\mathrm{C} 2-\mathrm{H}, \mathrm{C} 4-\mathrm{H}, \mathrm{C} 6-\mathrm{H}, \mathrm{C}-\mathrm{H})\end{array}$ \\
\hline $5 \mathbf{b}(\mathrm{NB})$ & 25 & $\begin{array}{l}209-210 \\
\left(\text { lit. }^{29)} 213-214\right)\end{array}$ & $\mathrm{C}, \mathrm{H}, \mathrm{N}$ & $\begin{array}{l}325.1688 \\
\left(\mathrm{C}_{20} \mathrm{H}_{23} \mathrm{NO}_{3}\right. \\
=325.1678)\end{array}$ & 1748.00 & $\begin{array}{l}\left(\mathrm{DMSO}-d_{6}\right) 7.32-7.35(\mathrm{~m}, 10 \mathrm{H}, \text { aryl } \mathrm{H}), 5.14(\mathrm{~s}, 1 \mathrm{H}, \\
\mathrm{C} 4-\mathrm{H}), 1.84-2.66\left(\mathrm{~m}, 11 \mathrm{H}, \mathrm{N}-\mathrm{CH}_{3} \text {, piperidinyl H) }\right.\end{array}$ \\
\hline 6a (TCPA) & 57 & $210-212$ & $\mathrm{C}, \mathrm{H}, \mathrm{N}$ & $\begin{array}{l}341.2352 \\
\left(\mathrm{C}_{22} \mathrm{H}_{31} \mathrm{NO}_{2}\right. \\
=341.2354)\end{array}$ & 1726.94 & $\begin{array}{l}\left(\mathrm{DMSO}-d_{6}\right) 7.24-7.33(\mathrm{~m}, 5 \mathrm{H}, \text { aryl } \mathrm{H}), 4.86-4.89(\mathrm{t}, \\
1 \mathrm{H}, \mathrm{C} 3-\mathrm{H}), 2.62\left(\mathrm{~s}, 3 \mathrm{H}, \mathrm{N}-\mathrm{CH}_{3}\right), 0.74-3.76(\mathrm{~m}, 22 \mathrm{H}, \\
\text { tropane, cyclohexyl H, CH) }\end{array}$ \\
\hline $6 \mathbf{b}$ (NCPA) & 53 & $243-246$ & $\mathrm{C}, \mathrm{H}, \mathrm{N}$ & $\begin{array}{l}315.2209 \\
\left(\mathrm{C}_{20} \mathrm{H}_{29} \mathrm{NO}_{2}\right. \\
=315.2206)\end{array}$ & 1724.87 & $\begin{array}{l}\left(\mathrm{DMSO}-d_{6}\right) 7.26-7.33(\mathrm{~m}, 5 \mathrm{H}, \text { aryl } \mathrm{H}), 4.99(\mathrm{~s}, 1 \mathrm{H}, \\
\mathrm{C} 4-\mathrm{H}), 2.81\left(\mathrm{~s}, 3 \mathrm{H}, \mathrm{N}-\mathrm{CH}_{3}\right), 0.77-3.34(\mathrm{~m}, 21 \mathrm{H}, \\
\text { piperidinyl } \mathrm{H}, \mathrm{CH})\end{array}$ \\
\hline 7a (TCPP) & 57 & 197-199 & $\mathrm{C}, \mathrm{H}$ & $\begin{array}{l}355.2519 \\
\left(\mathrm{C}_{23} \mathrm{H}_{33} \mathrm{NO}_{2}\right. \\
=355.2511)\end{array}$ & 1722.94 & $\begin{array}{l}\left(\mathrm{DMSO}-d_{6}\right) 7.41-7.24(\mathrm{~m}, 5 \mathrm{H}, \text { aryl H}), 4.97-4.99(\mathrm{t}, \\
1 \mathrm{H}, \mathrm{C} 3-\mathrm{H}), 3.31-3.29(\mathrm{~m}, 2 \mathrm{H}, \mathrm{C} 1-\mathrm{H}, \mathrm{C} 5-\mathrm{H}), 2.69(\mathrm{~s}, \\
\left.3 \mathrm{H}, \mathrm{N}-\mathrm{CH}_{3}\right), 1.53\left(\mathrm{~s}, 3 \mathrm{H}, \mathrm{Ar}-\mathrm{C}-\mathrm{CH}_{3}\right), 2.38-0.93(\mathrm{~m}, \\
19 \mathrm{H}, \text { cyclohexyl H, C2-H, C4-H, C6-H, C7-H) }\end{array}$ \\
\hline $7 b(\mathrm{NCPP})$ & 47 & $226-227$ & $\mathrm{C}, \mathrm{H}$ & $\begin{array}{l}329.2340 \\
\left(\mathrm{C}_{21} \mathrm{H}_{31} \mathrm{NO}_{2}\right. \\
=329.2355)\end{array}$ & 1721.01 & $\begin{array}{l}\left(\mathrm{CH}_{3} \mathrm{OD}\right) 7.45-7.22(\mathrm{~m}, 5 \mathrm{H}, \text { aryl } \mathrm{H}), 4.96(\mathrm{~s}, 1 \mathrm{H}, \\
\mathrm{C} 4-\mathrm{H}), 3.31-3.20(\mathrm{~m}, 4 \mathrm{H}, \mathrm{C} 2-\mathrm{H}, \mathrm{C} 6-\mathrm{H}), 2.82(\mathrm{~s}, 3 \mathrm{H}, \\
\left.\mathrm{N}-\mathrm{CH}_{3}\right), 1.53\left(\mathrm{~s}, 3 \mathrm{H}, \mathrm{Ar}-\mathrm{C}-\mathrm{CH}_{3}\right), 3.31-0.87(\mathrm{~m}, \\
15 \mathrm{H}, \text { cyclohexyl H, C3-H, C5-H) }\end{array}$ \\
\hline 8a (TCPG) & 47 & $143-146$ & $\mathrm{C}, \mathrm{H}$ & $\begin{array}{l}357.2278 \\
\left(\mathrm{C}_{22} \mathrm{H}_{31} \mathrm{NO}_{3}\right. \\
=357.2304)\end{array}$ & 1728.72 & $\begin{array}{l}\left(\mathrm{DMSO}-d_{6}\right) 7.24-7.56(\mathrm{~m}, 5 \mathrm{H}, \text { aryl } \mathrm{H}), 4.83-4.86(\mathrm{t}, \\
1 \mathrm{H}, \mathrm{C} 3-\mathrm{H}), 3.30-3.32(\mathrm{~m}, 2 \mathrm{H}, \mathrm{Cl}-\mathrm{H}, \mathrm{C} 5-\mathrm{H}), 3.60(\mathrm{~s}, \\
1 \mathrm{H}, \mathrm{OH}), 2.74\left(\mathrm{~s}, 3 \mathrm{H}, \mathrm{N}-\mathrm{CH}_{3}\right), 2.38-0.93(\mathrm{~m}, 19 \mathrm{H}, \\
\text { tropane, cyclohexyl H) }\end{array}$ \\
\hline $\mathbf{8 b}(\mathrm{NCPG})$ & 25 & $\begin{array}{l}245-246 \\
\left(\text { lit. }^{30)} 236.5-237.2\right)\end{array}$ & $\mathrm{C}, \mathrm{H}, \mathrm{N}$ & $\begin{array}{l}331.2161 \\
\left(\mathrm{C}_{20} \mathrm{H}_{29} \mathrm{NO}_{3}\right. \\
=331.2147)\end{array}$ & 1732.58 & $\begin{array}{l}\left.\text { (DMSO- } d_{6}\right) 7.23-7.59(\mathrm{~m}, 5 \mathrm{H}, \text { aryl } \mathrm{H}), 5.64(\mathrm{~s}, 1 \mathrm{H} \\
\mathrm{OH}), 5.03(\mathrm{~s}, 1 \mathrm{H}, \mathrm{C} 4-\mathrm{H}), 3.22-3.41(\mathrm{~m}, 4 \mathrm{H}, \mathrm{C} 2-\mathrm{H} \\
\mathrm{C} 6-\mathrm{H}), 2.69\left(\mathrm{~s}, 3 \mathrm{H}, \mathrm{N}-\mathrm{CH}_{3}\right), 0.97-2.51(\mathrm{~m}, 15 \mathrm{H}, \\
\text { C3-H, C5-H, cyclohexyl H) }\end{array}$ \\
\hline 9a (TM) & 20 & $41-42$ & - & - & 1740.11 & $\begin{array}{l}\left(\mathrm{DMSO}-d_{6}\right) 5.05-5.06(\mathrm{t}, 1 \mathrm{H}, \mathrm{C} 3-\mathrm{H}), 3.38-3.40(\mathrm{~m}, \\
2 \mathrm{H}, \mathrm{Cl}-\mathrm{H}, \mathrm{C} 5-\mathrm{H}), 3.71\left(\mathrm{~s}, 3 \mathrm{H}, \mathrm{CH}_{3}\right), 1.50-2.30(\mathrm{~m}, \\
8 \mathrm{H}, \mathrm{C} 2-\mathrm{H}, \mathrm{C} 4-\mathrm{H}, \mathrm{C} 6-\mathrm{H}, \mathrm{C}-\mathrm{C})\end{array}$ \\
\hline $9 b(N M)$ & 20 & $-f)$ & - & - & 1738.07 & $\begin{array}{l}\left(\mathrm{DMSO}-d_{6}\right) 5.15(\mathrm{~s}, 1 \mathrm{H}, \mathrm{C} 4-\mathrm{H}), 3.69\left(\mathrm{~s}, 3 \mathrm{H}, \mathrm{CH}_{3}\right) \\
2.63\left(\mathrm{~s}, 3 \mathrm{H}, \mathrm{N}-\mathrm{CH}_{3}\right), 1.40-3.27(\mathrm{~m}, 8 \mathrm{H}, \text { piperidinyl } \\
\mathrm{H})\end{array}$ \\
\hline
\end{tabular}

a) Melting point was determined for the $\mathrm{HCl}$ salt. b) Elemental analyses were within $0.4 \%$ of the theoretical values. c) Values in parentheses are theoretical values for the given formula of the compound. d) IR spectra were obtained from pressed $\mathrm{KBr}$ discs of the $\mathrm{HCl}$ salts. The position of the $v_{\mathrm{C}=\mathrm{O}}$ band of the ester is indicated. e) Chemical shifts are reported as ppm relative to tetramethylsilane. $\mathrm{s}=$ singlet; $\mathrm{m}=$ multiplet; $\mathrm{t}=$ triplet. $f$ ) Very hydroscopic, could not be determined. 
the solvent was removed in vacuo. Acetone $(50 \mathrm{ml})$ was added to the residue and the mixture was refluxed for $30 \mathrm{~min}$. On cooling, acetone was removed by distillation under reduced pressure and water was added. Strong ammonia solution was added dropwise, then the alkaline solution was extracted with diethyl ether. The ethereal layer was washed with water, dried with anhydrous $\mathrm{Na}_{2} \mathrm{SO}_{4}$ and evaporated in vacuo. The dried residue was converted to the $\mathrm{HCl}$ salt using ethereal $\mathrm{HCl}$. Recrystallization of the $\mathrm{HCl}$ salt was carried out from absolute ethanol and dry ether.

General Method for the Synthesis of the Methyl Ester of Benzilic Acid and Cyclohexylphenylglycolic Acid Methyl iodide $(0.06 \mathrm{~mol}, 3.7 \mathrm{ml})$ was added dropwise to a stirred mixture of the carboxylic acid $(0.03 \mathrm{~mol})$ and sodium bicarbonate $(0.04 \mathrm{~mol}, 3.36 \mathrm{~g})$ in DMF $(25 \mathrm{ml})$. Stirring was continued for $24 \mathrm{~h}$ at room temperature, then water $(100 \mathrm{ml})$ was added and the product extracted with diethyl ether. The ethereal layer was washed with water, dried with anhydrous $\mathrm{Na}_{2} \mathrm{SO}_{4}$ and evaporated in vacuo to afford the methyl ester of the carboxylic acid.

General Method for the Preparation of Esters TB, NB, TCPG and NCPG by Transesterification ${ }^{15)}$ The methyl ester of the carboxylic acid $(0.02 \mathrm{~mol})$, tropine $(0.02 \mathrm{~mol}, 2.8 \mathrm{~g})$ or $N$-methyl-4-piperidinol $(0.02 \mathrm{~mol}$, $2.3 \mathrm{~g})$, sodium methoxide $(1.9 \mathrm{mmol}, 100 \mathrm{mg})$ and $n$-heptane $(600 \mathrm{ml})$ were stirred together in a round-bottomed flask equipped with a Dean-Stark moisture determination apparatus. The mixture was refluxed for $1 \mathrm{~h}$, then further sodium methoxide $(100 \mathrm{mg})$ was added. A second addition $(50 \mathrm{mg})$ of sodium methoxide was made after another $8 \mathrm{~h}$ of refluxing, which was then continued for a further $6 \mathrm{~h}$. After cooling, the organic layer was washed repeatedly with water until neutral to litmus and evaporated in vacuo. The dried residue was converted to the $\mathrm{HCl}$ salt by using ethereal $\mathrm{HCl}$ and this was recrystallized from absolute ethanol and dry ether.

Methyl Cyclohexylphenylglycolate Cyclohexylphenylglycolic acid ${ }^{16}$ was synthesized with some modifications. Benzilic acid $(0.1 \mathrm{~mol})$ was dissolved in glacial acetic acid $(150 \mathrm{ml})$ and hydrogenated on a Parr hydrogenator at $60 \mathrm{psi}, 80^{\circ} \mathrm{C}$ for $4 \mathrm{~h}$ using platinum oxide $(1 \mathrm{~g})$ as a catalyst. Two more additions of platinum oxide $(0.5 \mathrm{~g})$ were made at $4 \mathrm{~h}$ intervals, after which the hydrogenation was continued for another $16 \mathrm{~h}$ at $60^{\circ} \mathrm{C}$. The catalyst was filtered off and the solvent was removed in vacuo. A white residue was obtained, which was thoroughly washed with water, dried and recrystallized from methanol $(3 \times)$. A portion of the residue $(6.8 \mathrm{~g})$ was reacted with methyl iodide $(0.06 \mathrm{~mol}, 3.73 \mathrm{ml})$ and $\mathrm{NaHCO}_{3}(0.04 \mathrm{~mol}, 3.36 \mathrm{~g})$ in $25 \mathrm{ml}$ dimethylformamide (DMF) according to the method described for synthesis of the methyl ester. A crude oil was obtained, which was applied to a silica gel column and eluted with ethyl acetate/hexane $(10: 90)$ to give $4.17 \mathrm{~g}(58 \%)$ of the product. IR (neat) $\mathrm{cm}^{-1}: v_{\mathrm{OH}} 3516.4, v_{\mathrm{CH}} 2932, v_{\mathrm{C}=\mathrm{o}} 1728.7, v_{\mathrm{C}=\mathrm{C}(=\mathrm{O})-\mathrm{o}}$ 1238.9. ${ }^{1} \mathrm{H}-\mathrm{NMR}\left(\mathrm{CDCl}_{3}\right) \delta 7.67-7.07(\mathrm{~m}, 5 \mathrm{H}$, aryl $\mathrm{H}), 3.70(\mathrm{~s}, 3 \mathrm{H}$, $\left.\mathrm{CH}_{3}\right), 1.93-0.70(\mathrm{~m}, 11 \mathrm{H}$, cyclohexyl $\mathrm{H})$.

2-Cyclohexyl-2-phenylpropionitrile ${ }^{14)}$ A solution of cyclohexyl chloride $(0.15 \mathrm{~mol}, 18 \mathrm{~g})$ in dry pyridine $(100 \mathrm{ml})$ was added dropwise to a vigorously stirred suspension of potassium tert-butoxide $(0.33 \mathrm{~mol}$, $40 \mathrm{~g}$ ) and $\alpha$-methylbenzyl cyanide $(0.15 \mathrm{~mol}, 20 \mathrm{~g}$ ) (Aldrich Chemical Company) while the temperature was maintained at $5-10^{\circ} \mathrm{C}$. Stirring was continued for $24 \mathrm{~h}$ at room temperature. Pouring the reaction mixture into an ice-cold solution of $1 \mathrm{M} \mathrm{HCl}$ resulted in the separation of a yellow oil, which was extracted with diethyl ether. The ethereal layer was washed with water, dried over anhydrous $\mathrm{Na}_{2} \mathrm{SO}_{4}$ and removed in vacuo. The crude oil was distilled under reduced pressure to give the product $(22.5 \mathrm{~g}$, $64 \%$ yield), at bp $120-123^{\circ} \mathrm{C}(10 \mathrm{mmHg})$. IR (neat) $\mathrm{cm}^{-1}: v_{\mathrm{C} \equiv \mathrm{N}} 2235.1$ ${ }^{1} \mathrm{H}-\mathrm{NMR}\left(\mathrm{DMSO}-d_{6}\right) \delta 7.25\left(\mathrm{~s}, 5 \mathrm{H}\right.$, aryl H) $1.67\left(\mathrm{~s}, 3 \mathrm{H}, \mathrm{CH}_{3}\right), 2.10-0.57$ (m, $11 \mathrm{H}$, cyclohexyl H).

2-Cyclohexyl-2-phenylpropanoic Acid ${ }^{13)}$ A mixture of 2-cyclohexyl2-phenylpropionitrile $(0.09 \mathrm{~mol}, 20 \mathrm{~g})$ and potassium hydroxide $(0.25 \mathrm{~mol}$, $14 \mathrm{~g})$ in diethylene glycol $(90 \mathrm{ml})$ was heated at $190^{\circ} \mathrm{C}$ for $72 \mathrm{~h}$. The mixture was cooled, water $(250 \mathrm{ml})$ was added, and the solution was extracted with diethyl ether. The aqueous layer was retained, acidified with dilute $\mathrm{HCl}$ and extracted with diethyl ether. The ethereal layer was washed with water, dried over anhydrous $\mathrm{Na}_{2} \mathrm{SO}_{4}$ and evaporated in vacuo. The pale brown solid obtained was recrystallized from pentane to give the product in $87 \%$ yield $\left(\mathrm{mp} 137-138^{\circ} \mathrm{C}\right.$, lit. $139-140^{\circ} \mathrm{C}$ ) ${ }^{13}$ ) IR $(\mathrm{KBr}) \mathrm{cm}^{-1}: v_{\mathrm{C}=\mathrm{O}} 1695.9 .{ }^{1} \mathrm{H}-\mathrm{NMR}\left(\mathrm{DMSO}-d_{6}\right) \delta 7.60-7.00(\mathrm{~m}, 5 \mathrm{H}$, aryl $\mathrm{H}), 1.43\left(\mathrm{~s}, 3 \mathrm{H}, \mathrm{CH}_{3}\right), 1.87-0.73(\mathrm{~m}, 11 \mathrm{H}$, cyclohexyl $\mathrm{H})$.

2. Pharmacology. Aortic Ring Preparation Aortic rings were prepared from rat and rabbit aortas. The animal (male Sprague Dawley rat, $275 \pm 25 \mathrm{~g}$ or male rabbit, $1.75 \pm 0.25 \mathrm{~kg}$ ) was paralyzed by cervical dislocation, and killed immediately by decapitation, then the aortic rings were isolated as described. ${ }^{17,18)}$ In the case of rabbit aorta, the endothelium was removed by gently rubbing the intima with a wooden stick for $30-60 \mathrm{~s}$.

Briefly, each aorta was freed of adhering tissues and cut into $2 \mathrm{~mm}$ segments. Each segment was suspended with a resting tension of $1 \mathrm{~g}$ ( $1.5 \mathrm{~g}$ for rabbit aorta) in a $10 \mathrm{ml}$ organ bath containing Krebs-Ringer bicarbonate solution of composition (mM) NaCl 118, $\mathrm{KCl} 5, \mathrm{NaHCO}_{3}$ 25, glucose $10, \mathrm{CaCl}_{2} 2.5, \mathrm{MgSO}_{4} 7 \mathrm{H}_{2} \mathrm{O}$ 1.2, $\mathrm{KH}_{2} \mathrm{PO}_{4} 1.2$ and EDTA 0.026 . One end of the aortic ring was connected via a silk thread to a isometric transducer coupled to a polygraph (Ugo Basille Quartet), while the other end was attached to the base of a steel gas inlet tube. The bath was aerated with a gas mixture of $95 \% \mathrm{O}_{2}-5 \% \mathrm{CO}_{2}$ and maintained at $37^{\circ} \mathrm{C}$. The tissue was equilibrated for at least $60 \mathrm{~min}$ before addition of drugs.

Effects of Test Compounds on ACh-Induced Relaxation of Phenylepherine-Contracted Rat Aortic Rings Using a Single Concentration of ACh Phenylepherine $\left(10^{-7} \mathrm{M}\right)$ was added to the bath to produce a contraction of the rat aortic ring which was sustainable for $15 \mathrm{~min}$. ACh $\left(10^{-6} \mathrm{M}\right)$ was then added to produce a relaxation response. As endothelium intactness was essential for the experiment, only rings with greater than $70 \%$ maximum relaxation were used for further experiments.

After $20 \mathrm{~min}$ of re-equilibration with two washings, each ring was incubated with a fixed concentration of the test compound for $60 \mathrm{~min}$. Subsequently, phenylepherine $\left(10^{-7} \mathrm{M}\right)$ and $\mathrm{ACh}\left(10^{-6} \mathrm{M}\right)$ were added successively to the bath to contract and relax the aortic ring, respectively. The ACh-induced relaxations in the absence and presence of the test compound were compared. The experiment was carried out using no less than 3 different concentrations $\left(10^{-5}-10^{-9} \mathrm{M}\right)$ of each compound. The concentration required to inhibit $\mathrm{ACh}$-induced relaxation by $50 \%$ $\left(\mathrm{EC}_{50}\right)$ was determined for each compound.

Effects of Test Compounds on ACh-Induced Contraction of Norepinephrine-Precontracted Denuded Rabbit Aortic Rings Using a Single Concentration of $\mathrm{ACh}$ Norepinephrine $\left(10^{-8} \mathrm{M}\right)$ was added to the bath to produce a sustainable contraction of the denuded rabbit aortic ring. ACh $\left(10^{-4} \mathrm{M}\right)$ was then added to produce a relaxation response. The effects of the test compounds were evaluated in the same manner as described earlier. At least 3 different concentrations of each compound $\left(10^{-5}-10^{-9} \mathrm{M}\right)$ were tested to determine the concentration required to inhibit $\mathrm{ACh}$-induced contraction by $50 \%\left(\mathrm{EC}_{50}\right)$.

Effects of Test Compounds on ACh-Induced Relaxation of Phenylepherine-Contracted Rat Aortic Rings Using Cumulative Concentrations of ACh This experiment was carried out using atropine, 4-DAMP, AF-DX 116 and those esters with $\mathrm{EC}_{50}$ values in the range of $10^{-8}$ to $10^{-9} \mathrm{M}$, as well as esters which show selectivity in their action (NPA, TPP, NPP, NCPP). Rat aortic rings were isolated and mounted as described earlier. Phenylepherine $\left(10^{-7} \mathrm{M}\right)$ was added to induce a sustainable contraction. Cumulative concentrations of $\mathrm{ACh}\left(10^{-3}-10^{-9} \mathrm{M}\right)$ were then added at 2 min intervals to produce a concentration-dependent relaxation response. After washing by overflow, the tissue was rested and washed twice over a $20 \mathrm{~min}$ period. At least 3 different concentrations $\left(10^{-8}-10^{-10} \mathrm{M}\right)$ of the test compound were added separately to the bath and left for $60 \mathrm{~min}$, after which the concentration-dependent relaxation of phenylepherine-induced contraction was repeated using cumulative additions of $\mathrm{ACh}$.

Eight parallel concentration-dependent relaxation curves were similarly obtained as controls. Since the concentration-dependent relaxation curves obtained in the presence of antagonists were second-round concentration-dependent curves, they were compared to the second parallel concentration-dependent relaxation curve for the calculation of the concentration ratios to be used for the Schild regression.

Effects of Test Compounds on ACh-Induced Contraction of Norepinephrine-Contracted Rabbit Aortic Rings Using Cumulative Concentrations of $\mathrm{ACh}$ This experiment was carried out using atropine, 4-DAMP, $A F-D X 116$ and those esters which have $\mathrm{EC}_{50}$ values in the range of $10^{-8}$ to $10^{-9} \mathrm{M}$ as well as esters which show selectivity in their action (NPA, TPP, NPP, NCPP). Endothelium-denuded rabbit aortic rings were isolated and mounted as described earlier. Norepinephrine $\left(10^{-8} \mathrm{M}\right)$ was added to induce a sustainable contraction. Cumulative additions of $\mathrm{ACh}\left(10^{-3}-10^{-6} \mathrm{M}\right)$ were made at $2 \mathrm{~min}$ intervals to produce a concentration-dependent contraction response. Schild's analysis of the test compounds was conducted in the same manner as described earlier.

Data Analysis $\mathrm{The}_{\mathrm{EC}}$ of each test compound was evaluated using the software Pharmacological Calculation System Version 4.2., from a 
plot of the ratio of $\mathrm{ACh}$-induced response in the presence and absence of test compound versus its concentration. For the Schild's analysis, the ACh response (contraction/relaxation) was expressed as mean $\pm S E M$ and comparisons between means were made using Student's $t$ test. Differences between means were considered significant if $p<0.05$. The concentration ratio $\left(\mathrm{Dr}\right.$, defined as the ratio of $\mathrm{EC}_{50}$ or $\mathrm{EC}_{70}$ of $\mathrm{ACh}$ in the presence of a test compound to the $\mathrm{EC}_{50}$ or $\mathrm{EC}_{70}$ of $\mathrm{ACh}$ in its absence) was determined for different concentrations of test compound from appropriate $\mathrm{ACh}$ cumulative dose-response curves. The data were plotted according to the Schild equation ${ }^{19)}$ :

$$
\log (\mathrm{Dr}-1)=\log [\mathrm{B}]-\log K_{\mathrm{B}}
$$

where $K_{\mathrm{B}}$ is the dissociation equilibrium constant for the antagonist B.

Regression of $\log (\mathrm{Dr}-1)$ against $\log [\mathrm{B}]$ was computed using Lotus $123^{\mathrm{R}}$, from which the gradient and $x$-intercept of the Schild regression were obtained. The ratio of the $x$-intercept to the gradient gave $\mathrm{pA}_{2}$, which is a logarithmic measure of the potency of the antagonist. ${ }^{30)}$ The statistic used to verify the variation of the gradient $(\beta)$ from unity is the $t$ statistic $[\beta-1 / \mathrm{SE}(\beta)]$ with $n-2$ degrees of freedom. ${ }^{17)}$

Materials $\mathrm{ACh}$ chloride, phenylepherine hydrochloride, norepinephrine hydrochloride and atropine sulphate were purchased from Sigma Chemical Company. AF-DX 116 was a gift from Boehringer Ingelheim. DAMP methobromide was a gift from Dr. R.B. Barlow, University of Bristol, $\mathrm{UK}$. The esters were used as their $\mathrm{HCl}$ salts and all drug solutions were prepared in distilled water.

3. Determination of Steric, Hydrophobic and Electronic Parameters for QSAR The hydrophobicity of the esters were assessed from their capacity factors $\left(k^{\prime}\right)$ determined by reverse-phase HPLC on a LiChrosorb $^{\mathrm{R}}$ RP-18 stationary phase, using as mobile phase varying concentrations of methanol and a buffer $(\mathrm{pH} 11.9)$ prepared from $0.05 \mathrm{M}$ sodium acetate, $0.2 \mathrm{M} \mathrm{NaCl}$ and $0.05 \mathrm{M}$ triethylamine. ${ }^{31)}$

The electronic effect of $\mathrm{R}$ in the acyl moiety $\mathrm{R}-\mathrm{CO}$-was assessed using Taft's polar parameter $\sigma^{*}{ }^{32)}$ and also by an indirect method in which the chemical shift of the carbonyl carbon was determined from the ${ }^{13} \mathrm{C}-\mathrm{NMR}$ spectra of the esters (4 $\mathrm{mm}$ in $\mathrm{CD}_{3} \mathrm{OD}$, TMS as the reference) using a Bruker ACF 300 instrument. The electronic effect of $\mathrm{R}$ is given by $\Delta \delta$ which is the difference between the chemical shifts of the carbony carbon in the ester $\left(\delta_{\mathrm{i}}\right)$ and that of the methyl ester $\left(\delta_{\mathrm{Me}}\right)$ of tropine (171.543 ppm) or $N$-methylpiperidin-4-ol (170.943 ppm).

$$
\Delta \delta=\delta_{\mathrm{i}}-\delta_{\mathrm{Me}}
$$

The molecular volume of the ester was used as the steric parameter and it was determined from the low-energy conformation of the ester obtained by minimization using the SYBYL 6.2 (Tripos Inc., St Louis, MO 63144) Tripos force field (MAXIMIN2), continued until the rms gradient was less than $0.001 \mathrm{kcal} \mathrm{mol}^{-1}$. Linear and stepwise multiple linear regressions of the results were carried out on SPSS for Windows ${ }^{\circledR}$ (SPSS Inc., Chicago, IL) and the following statistical parameters were recorded for each regression equation: $95 \%$ confidence intervals for intercept and gradient, the number of points $(n)$, the correlation coefficient $\left(r^{2}\right)$, the significance of the regression model $(F)$ and the standard error (S.E.).

CoMFA The energy-minimized conformations of the 18 esters were aligned using the multisearch option in DISCO. Some of the esters (TPP, NPP, TCPP, NCPP, TCPG, NCPG) have a chiral center in the acyl moiety, but were not resolved into enantiomers for biological testing. It is possible that the activity of the racemate is wholly due to one enantiomer, in which case the activity would be increased by two-fold or $0.30 \mathrm{pK}_{\mathrm{EC}_{50}}$ units. Following other reports, ${ }^{33)}$ we have obtained the energy-minimized conformations of both enantiomers and selected only the stereoisomer with the lower conformational energy (assumed to be the "active" conformation) for alignment in DISCO. Several alignment models were obtained by DISCO and the best model (evaluated by rms fit, volume overlap, Tol ${ }_{\text {max }}$ and $\mathrm{D}_{\text {mean }}$ ) was selected for CoMFA.

CoMFA analysis was carried out using the QSAR module of SYBYL 6.2. Computation of atomic charge was carried out using the Gasteiger Huckel method. The steric (van der Waals interaction) and electrostatic (Coulombic) potential energy fields were calculated at each lattice intersection on a regularly $(2 \AA)$ spaced grid, using a positively charged carbon as the probe atom. The variables were scaled using CoMFA standard scaling which gives identical weight to CoMFA fields and additional variables. Column filtering was set at $2.0 \mathrm{kcal}$ and steric/ electrostatic cutoff values at $30 \mathrm{kcal} / \mathrm{mol}$. Calculated steric and electrostatic values served as regressors for the partial least-squares anal- ysis to explore a possible correlation between these values and biological activity. Partial least-squares analyses was carried out with the optimal number of components equal to five and "leave one out" cross validation. The optimal number of components from this analysis was used in the final analysis with zero cross validation groups for the construction of the coefficient contour maps.

Initially, two CoMFA determinations were made: one in which the biological activities of the chiral esters were assigned values determined from the functional assays ("unmodified") and another in which the activities were increased by $0.30 \mathrm{p} K_{\mathrm{EC}_{50}}$ units ("modified"), based on the assumption that activity resides in the enantiomer with the active conformation. It was found that the determinations using either values gave rise to qualitatively similar results. An analysis was also carried out using the hydrophobic parameter $\log k_{\mathrm{w}}$, weighted equally with the CoMFA steric and electrostatic values, as the regressor.

Acknowledgements $\mathrm{Xu}$ Rong gratefully acknowledges a research scholarship from the National University of Singapore. This work was funded by research grant RP 920306 from the National University of Singapore.

\section{References}

1) Eglen R. M., Watson N., Pharmacol. Toxicol., 78, 59-68 (1996).

2) Eberlein W. R., Hasselbach K. M., Mayer N., Mihm G., Rudolf K., Doods H. N., "Trends in Receptor Research," Elsevier Science Publishers, Amsterdam, 1992, p. 231-249.

3) Doods H. N., Quirion R., Mihm G., Engel W., Rudolf K., Entzeroth M. L., Schiavi G. B., Ladinsky H., Bechtel E. I., Ensinger H. A., Mendla K. D., Eberlein W., Life Sci., 52, 497-503(1993).

4) Gross N. J., Skorodin M. S., Amer. Rev. Respir. Dis., 129, 856-870 (1984).

5) Andersson K. E., Pharmacol. Rev., 45, 253-308 (1993).

6) Wallis R. M., Life Sci., 56, 861-868 (1995).

7) Barlow R. B., Burston K. N., Vis A., Br. J. Pharmac., 68, 141-142P (1980).

8) Barlow R. B., Shepherd M. K., Br. J. Pharmac., 89, 837-843 (1986).

9) Barlow R. B., Shepherd M. K., Tydeman H., Veale M. A., Br. J. Pharmac., 94, 947-951 (1988).

10) Recanatini M., Tumiatti V., Budriesi R., Chiarini A., Sabatino P., Bolognesi M. L., Melchiorre C., Bioorg. Med. Chem., 3, 267-277 (1995).

11) Tumiatti V., Recanatini M., Minarini A., Melchiorre C., Chiarini A., Budriesi R., Bolognesi M. L., Il Farmaco., 47, 1133-1147 (1992).

12) Vogel A. I., "A Textbook of Practical Organic Chemistry", ELBS Longman, London, 1978, Chapter 3.

13) Hill R. K., Cullison D. A., J. Amer. Chem. Soc., 95, 1229-1238 (1975).

14) Leader H., Gordon R. K., Baumgold J., Boyd V. L., Newman A. H., Smejkal R. M., Chiang P. K., J. Med. Chem., 35, 1290-1295 (1992).

15) Cannon J. G., J. Org. Chem., 25, 959-962 (1960).

16) Biel J. H., Friedman H. L., Leiser H. A., Sprengelfr E. P., J. Amer. Chem. Soc., 74, 1485-1488 (1952).

17) Sim M. K., Lim B. C., Endothelium, 1, 109-114 (1993).

18) Jaiswal N., Lambrecht G., Mutschler E., Tacke R., Malik K. U., J. Pharmacol. Exp. Therap., 258, 842-850 (1991).

19) Arunlakshana O., Schild H. O., Br. J. Pharmac., 14, 48-58 (1959).

20) Tallarida R. J., Cowan A., Adler M. W., Life Sci., 25, 637-654 (1979).

21) Kenakin T. P., Beek D., Naunyn-Schmiedeberg's Arch. Pharmacol., 335, 103-108 (1987).

22) Kenakin T. P., "Pharmacologic Analysis of Drug-receptor Interaction," Raven Press, 1987, p. 236.

23) Visser T. J., van Waarde A., Jansen T. J. H., Visser G. M., van der Mark T. W., Kraan J., Ensing K., Vaalburg W., J. Med. Chem., 40, 117-124 (1997).

24) Nordvall G., Sundquist S., Johansson G., Glas G., Nilvebrant L., Hacksell U., J. Med. Chem., 39, $3269-3277$ (1996).

25) Nilsson B. M., Sundquist S., Johansson G., Nordvall G., Glas G., Nilvebrant L., Hacksell U., J. Med. Chem., 38, 473-487 (1995).

26) Wernly-Chung G. N., Mayer J. M., Tsantili-Kakoulidou A., Testa 
B., Int. J. Pharmaceut., 63, 129-134 (1990).

27) Feriani A., Gaviraghi G., Toson G., Mor M., Barbieri A., Grana E., Boselli C., Guarneri M., Simoni D., Manfredini S., J. Med. Chem., 37, 4278-4287 (1994).

28) Martin Y.C., Lin C. T., "The Practice of Medicinal Chemistry," ed. by Wermuth C. G., Academic Press, London, 1996, Chapter 23.

29) Taylor E. C., McKillop A., Hawks G. H., Organic Syntheses, 52,
$36-39(1972)$

30) Mackay D., J. Pharm. Pharmacol., 30, 312-313 (1978).

31) Xu R., Go M. L., Chem. Pharm. Bull., 45, 476-481 (1997).

32) Taft R. W., Jr., "Steric Effects in Organic Chemistry," ed. by Newman M. S., John Wiley \& Sons, New York, 1956, Chapter 13.

33) Greco G., Novellino E., Silipo C., Vittoria A., Quant. Struct.-Act. Relat., 10, 289-299 (1991). 